\title{
Seasonal and annual mass balances of Mera and Pokalde glaciers (Nepal Himalaya) since 2007
}

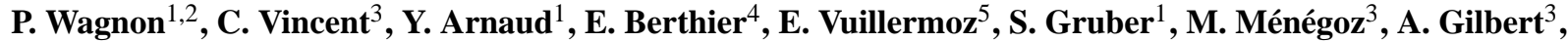 \\ M. Dumont ${ }^{6}$, J. M. Shea ${ }^{2}$, D. Stumm ${ }^{2}$, and B. K. Pokhrel ${ }^{7}$ \\ ${ }^{1}$ IRD/UJF - Grenoble 1/CNRS/G-INP, LTHE UMR5564, LGGE UMR5183, Grenoble, 38402, France \\ ${ }^{2}$ ICIMOD, GPO Box 3226, Kathmandu, Nepal \\ ${ }^{3}$ UJF - Grenoble 1/CNRS, Laboratoire de Glaciologie et Géophysique de l'Environnement (LGGE) UMR5183, \\ Grenoble, 38041, France \\ ${ }^{4}$ LEGOS, CNRS, Université de Toulouse, 14 av. Edouard Belin, 31400 Toulouse, France \\ ${ }^{5}$ Ev-K2-CNR Committee, Via San Bernardino, 145 - 24126 Bergamo, Italy \\ ${ }^{6}$ Météo-France - CNRS, CNRM - GAME UMR3589, CEN, Grenoble, France \\ ${ }^{7}$ DHM, Department of Hydrology and Meteorology, Babarmahal, Kathmandu, Nepal
}

Correspondence to: P. Wagnon (patrick.wagnon@ujf-grenoble.fr)

Received: 21 June 2013 - Published in The Cryosphere Discuss.: 5 July 2013

Revised: 26 September 2013 - Accepted: 11 October 2013 - Published: 19 November 2013

\begin{abstract}
In the Everest region, Nepal, ground-based monitoring programmes were started on the debris-free Mera Glacier $\left(27.7^{\circ} \mathrm{N}, 86.9^{\circ} \mathrm{E} ; 5.1 \mathrm{~km}^{2}, 6420\right.$ to $4940 \mathrm{~m}$ a.s.1.) in 2007 and on the small Pokalde Glacier $\left(27.9^{\circ} \mathrm{N}, 86.8^{\circ} \mathrm{E}\right.$; $0.1 \mathrm{~km}^{2}, 5690$ to $5430 \mathrm{ma}$ a.s.1., $\sim 25 \mathrm{~km}$ north of Mera Glacier) in 2009. These glaciers lie on the southern flank of the central Himalaya under the direct influence of the Indian monsoon and receive more than $80 \%$ of their annual precipitation in summer (June to September). Despite a large interannual variability with glacier-wide mass balances ranging from $-0.67 \pm 0.28 \mathrm{~m}$ w.e. in 2011-2012 (Equilibriumline altitude (ELA) at $\sim 5800 \mathrm{~m}$ a.s.l.) to $+0.46 \pm 0.28 \mathrm{~m}$ w.e. in 2010-2011 (ELA at $~ 5340$ m a.s.1.), Mera Glacier has been shrinking at a moderate mass balance rate of $-0.08 \pm 0.28 \mathrm{~m}$ w.e. $\mathrm{yr}^{-1}$ since 2007 . Ice fluxes measured at two distinct transverse cross sections at $\sim 5350 \mathrm{~m}$ a.s.l. and $\sim 5520 \mathrm{~m}$ a.s.l. confirm that the mean state of this glacier over the last one or two decades corresponds to a limited mass loss, in agreement with remotely-sensed regionwide mass balances of the Everest area. Seasonal mass balance measurements show that ablation and accumulation are concomitant in summer which in turn is the key season controlling the annual glacier-wide mass balance. Unexpectedly, ablation occurs at all elevations in winter due to wind erosion and sublimation, with remobilised snow poten-
\end{abstract}

tially being sublimated in the atmosphere. Between 2009 and 2012, the small Pokalde Glacier lost mass more rapidly than Mera Glacier with respective mean glacier-wide mass balances of -0.72 and $-0.23 \pm 0.28 \mathrm{~m}$ w.e. $\mathrm{yr}^{-1}$. Low-elevation glaciers, such as Pokalde Glacier, have been usually preferred for in-situ observations in Nepal and more generally in the Himalayas, which may explain why compilations of ground-based mass balances are biased toward negative values compared with the regional mean under the present-day climate.

\section{Introduction}

Since the erroneous statement in the 2007 Intergovernmental Panel on Climate Change (IPCC) Fourth Assessment Report that Himalayan glaciers could disappear in the coming decades if the Earth keeps warming at the current rate (Cogley et al., 2010), these glaciers have drawn the attention of a growing number of scientists (e.g. Bolch et al., 2012; Kääb et al., 2012). Almost every study stresses that major gaps remain in our knowledge of the behaviour of Himalayan glaciers mainly due to "insufficient numbers of in-situ measurements, for which remote sensing only partly substitutes" (Bolch et al., 2012). This paucity of appropriate 
glacier data is of particular concern while considering that Himalayan glaciers have significant social and economic impacts on densely populated regions through water resources (e.g. Kehrwald et al., 2008; Immerzeel et al., 2010; Kaser et al., 2010; Kääb et al., 2012; Nepal et al., 2012; Neil et al., 2013; Gardelle et al., 2013) or glacial hazards (e.g. Bajracharya and Mool, 2009).

Karakoram-Himalayan glaciers cover the largest glacierized area on Earth outside the polar regions $\left(\sim 40800 \mathrm{~km}^{2}\right.$; Bolch et al., 2012). They experience contrasting precipitation regimes, with a decreasing influence of the westerlies from west to east, and a simultaneous increasing influence of the Indian and Asian monsoons, allowing two striking gradients to emerge: an east-to-west rainfall gradient along the Himalayan foreland, and a south-to-north gradient across the Himalayan range due to topography and relief (Burbank et al., 2003; Bookhagen and Burbank, 2006, 2010). This complex climate diversity results in a contrasting pattern of glacier change throughout the range, mainly revealed by studies using remote-sensing data (e.g. Fujita and Nuimura, 2011; Scherler et al., 2011; Bolch et al., 2012; Kääb et al., 2012; Gardelle et al., 2013; Gardner et al., 2013). Groundbased observations everywhere along the entire range are not possible, but in-situ measurements are needed to confirm remotely-sensed observations and quantify important variables not measurable from space such as annual and seasonal mass balances, mass balance gradients and snow/ice melt factors for degree-day models.

Our present study contributes to fill this data gap and presents results from extensive mass balance and dynamics measurements conducted in the Everest region (central Himalaya, Nepal), on Mera Glacier since 2007 (Hinku-Hunku valley), and on Pokalde Glacier since 2009 (Khumbu valley). Recently, Vincent et al. (2013) provided an exhaustive compilation of all in-situ mass balance series available in western Himalaya (Northern India), showing that these series are short-term ( $<10 \mathrm{yr}$ usually), discontinuous and not representative of the mass balance of this large region. In central Himalaya and Nepal especially, the situation is similar even though the Japanese conducted some pioneering surveys in the 1970s on AX010 Glacier $\left(\sim 0.4 \mathrm{~km}^{2}\right.$, Shorong Himal, $\sim 30 \mathrm{~km}$ southwest of Mera Glacier), on Yala Glacier $\left(\sim 1.9 \mathrm{~km}^{2}\right.$, Langtang Himal central Nepal) and on Rikha Samba Glacier $\left(\sim 4.6 \mathrm{~km}^{2}\right.$, Lower Mustang - western Nepal) (e.g. Ageta et al., 1980; Ageta and Higuchi, 1984; Fujita and Nuimura, 2011). Fujita et al. (2001a) reported systematic negative glacierwide mass balances for AX010 Glacier between 1978-1999 $\left(-0.6 \mathrm{mw}\right.$ w.e. $\mathrm{yr}^{-1}$ for $1978-1991 ;-1.0 \mathrm{mw}$ w.e. $\mathrm{yr}^{-1}$ for 1991-1996 and $-0.8 \mathrm{~m}$ w.e. $\mathrm{yr}^{-1}$ for 1996-1999) based on long-term surface-elevation change observations and $4 \mathrm{yr}$ of glaciological annual mass balance observations (19951999). Fujita and Nuimura (2011) extended this study until 2010 relying on additional geodetic observations conducted in 2008-2010 and using an energy-mass balance model with downscaled gridded climate datasets. They also included Yala and Rikha Samba glaciers in their study and concluded that glaciers have been experiencing negative areaaveraged mass balances for the last three decades (from $\sim-0.75 \mathrm{~m}$ w.e. $\mathrm{yr}^{-1}$ for Yala and AX010 glaciers to $\sim-0.5$ $\mathrm{m}$ w.e. $\mathrm{yr}^{-1}$ for Rikha Samba Glacier located in a drier climate). Kadota et al. (2000) followed by Nuimura et al. (2011) also measured surface lowering of Khumbu Glacier between 1978 and 1995 and then again in 2004. They observed no significant elevation change near the terminus over the whole studied period, a remarkable acceleration of surface lowering after 1995 in the middle part of the debris-covered area (present elevation change rate of $\sim 2 \mathrm{~m} \mathrm{yr}^{-1}$ ) and a temporally consistent lowering rate in the uppermost part of this area $\left(\sim 0.6 \mathrm{~m} \mathrm{yr}^{-1}\right)$. Even though Japanese glaciologists have intermittently observed the changes of the surface elevation of various Nepalese glaciers by geodetic surveys, only four years of annual mass balances are available on AX010 Glacier (1995-1999), making the 5 yr Mera Glacier series presented here the longest continuous series of measured annual mass balance in Nepal. Decadal mass balances measured using the geodetic method are important but they do not replace seasonal mass balance measurements that are needed to analyze the climatic causes of mass balance changes. Since 2011, annual in-situ mass balance surveys on Yala and Rikha Samba glaciers have been conducted by ICIMOD (International Centre for Integrated Mountain Development, Kathmandu, Nepal) and partner institutes.

Remote-sensing studies in Nepal also indicate that glacier mass balances are negative on average. Bolch et al. (2011) reported a mass balance of $-0.32 \pm 0.08 \mathrm{mw}$.e. $\mathrm{yr}^{-1}$ between 1970 and 2007 over $62 \mathrm{~km}^{2}$ of glaciers in the Everest area, while for a larger group of glaciers covering $183 \mathrm{~km}^{2}$ in the same area, Nuimura et al. (2012) measured a mass balance of $-0.40 \pm 0.25 \mathrm{~m}$ w.e. $\mathrm{yr}^{-1}$ over $1992-2008$. Recently, Gardelle et al. (2013) found a region-wide mass balance of $-0.26 \pm 0.13 \mathrm{~m}$ w.e. $\mathrm{yr}^{-1}$ over $2000-2011$ for a $1461 \mathrm{~km}^{2}$ glacierized area, in agreement with the value $\left(-0.30 \pm 0.09 \mathrm{~m}\right.$ w.e. $\left.\mathrm{yr}^{-1}\right)$ reported by Kääb et al. (2012) for East Nepal and Bhutan for 2003-2008.

Apart from the geographical description of the glaciers and the study area, the aim of this contribution is to present $5 \mathrm{yr}$ of mass balance, annual surface velocity and thickness measurements of Mera Glacier, and to compare to the seasonal mass balances of Pokalde Glacier. The measurements presented in this study will allow a better assessment and understanding of glacier mass balance in this part of Nepal. Indeed, Mera Glacier is planned to become a benchmark glacier for process-understanding in this part of the Himalayan range, following the basic concepts of international climate-related glacier monitoring ("tier-2" level described in Haeberli et al., 2002; or Paul et al., 2007). This glacier is likely to be included into the GLACIOCLIM network whose aim is to select a limited number of glaciers representative of various climates of the world in order 
Table 1. List of geographical and topographical characteristics of Mera Glacier. $\mathrm{ELA}_{0}$ and $\mathrm{AAR}_{0}$ are the calculated equilibriumline altitude and accumulation-area ratio values respectively for a zero glacier-wide balance given the 2012 hypsography. Mean annual temperature at $\mathrm{ELA}_{0}$ is derived from the AWS located at $5360 \mathrm{~m}$ a.s.l. applying a standard lapse rate of $-0.0065^{\circ} \mathrm{C} \mathrm{m}^{-1}$.

\begin{tabular}{|c|c|}
\hline \multicolumn{2}{|c|}{ General features } \\
\hline Country - Region & Nepal - Everest region \\
\hline Mountain range & Central Himalaya \\
\hline Drainage system & Dudh Koshi basin - Ganges river \\
\hline Climate & Indian monsoon zone \\
\hline \multicolumn{2}{|c|}{ Glacier characteristics } \\
\hline Latitude/Longitude & $27.7^{\circ} \mathrm{N} / 86.9^{\circ} \mathrm{E}$ \\
\hline Max./Min. elevation & $6420 / \sim 4940$ m a.s.l. \\
\hline Total glacierized area & $5.1 \mathrm{~km}^{2}$ \\
\hline Mean orientation & North \\
\hline \multicolumn{2}{|c|}{ Measurement information } \\
\hline Total number of ablation stakes & 28 to 45 (between 5000 and $5550 \mathrm{~m}$ a.s.1.) \\
\hline Total number of pits/drilling sites & 5 (between 5650 and $6350 \mathrm{~m}$ a.s.l.) \\
\hline Measurements frequency & 2/year: Apr and Nov since 2013 \\
\hline \multicolumn{2}{|c|}{ Mass balance information } \\
\hline $\mathrm{ELA}_{0}$ & $\sim 5550 \mathrm{~m}$ a.s.l. \\
\hline $\mathrm{AAR}_{0}$ & $\sim 0.59$ \\
\hline Mean annual temperature at $\mathrm{ELA}_{0}$ & $\sim-2.6^{\circ} \mathrm{C}$ \\
\hline
\end{tabular}

to better understand the climate-glacier relationship (http: //www-lgge.obs.ujf-grenoble.fr/ServiceObs/index.htm).

\section{Site description}

Mera Glacier $\left(27.7^{\circ} \mathrm{N}, 86.9^{\circ} \mathrm{E}, 5.1 \mathrm{~km}^{2}\right)$ is a debris-free glacier straddling Hinku valley and Hunku valley (Dudh Koshi basin, Everest region, central Himalaya), and has been monitored since 2007 (Figs. 1 and 2). Mera Peak is popular among the climbers because of its gentle slopes (mean slope of $\sim 16^{\circ}$ ) and its 5 to 7 day access from Lukla airport. From the summit at $6420 \mathrm{~m}$ a.s.l., the glacier flows north and divides into two main branches at $5800 \mathrm{~m}$ a.s.1. The main branch flows north and then west down to its snout at $4940 \mathrm{~m}$ a.s.l. while the second branch is northeast orientated with its lowest elevation at $5260 \mathrm{~m}$ a.s.l. These two branches are referred as Mera and Naulek, respectively (Fig. 2). Naulek is also part of the glacierized complex covering the northern slopes of Naulek Peak located $\sim 3.5 \mathrm{~km}$ southeast of Mera Peak. Table 1 gives a list of geographical and topographical characteristics of Mera Glacier as well as some basic mass balance information calculated according to mass balance data of this study (see Sect. 5.1). Mera Peak is one of the most southern mountains of the region, and thus occupies a frontal position against the Indian monsoon flux (e.g. Bookhagen and Burbank, 2006).

Pokalde Glacier $\left(27.9^{\circ} \mathrm{N}, 86.8^{\circ} \mathrm{E} ; 0.1 \mathrm{~km}^{2}\right)$ is located $\sim 25 \mathrm{~km}$ north of Mera Glacier, in Khumbu valley (Fig. 1). Due to its interior position in the range, this glacier is effi- ciently sheltered from the wet summer monsoon influx leading to a drier climate than on Mera Glacier (Bookhagen and Burbank, 2006). This north-oriented glacier flows from 5690 to $5430 \mathrm{~m}$ a.s.1., is accessible from Ev-K2-CNR Pyramid permanent research observatory, and has been monitored since 2009 (Fig. 3).

\section{Climatic setting}

Figure 4 shows the mean annual cycle of monthly precipitation and monthly air temperature (years 2003 to 2012) recorded at four meteorological stations operated by Ev-K2CNR in Lukla (2660 m a.s.1.), Namche Bazar (3570 m a.s.1.), Pheriche (4260 m a.s.1.) and Pyramid (5035 m a.s.1.) (Fig. 1). Precipitation sensors at these locations are tipping buckets usually used for rainfall measurements, and may under-catch part of the solid precipitation. Therefore, precipitation at the two highest stations (Pyramid and Pheriche) is likely underestimated. This dataset has gaps (listed in Fig. 4 caption) but is sufficient to describe annual local climate cycles. Using the ten-year 2003-2012 dataset, the mean annual cycle of monthly air temperature (or precipitation) has been obtained by averaging all the monthly temperature available for each month of the year (i.e. all records from the January months between 2003 and 2012 were averaged together to give the monthly temperature of January in Fig. 4). When data were missing during more than 10 days in a month, the corresponding monthly record was not considered for the averaging. It is noteworthy to say that the resulting mean annual cycle of monthly temperature or precipitation is different from the real mean cycle for the 2003-2012 period because of numerous and random gaps in the dataset, but it allows us to discuss the local climate. Both air temperature and precipitation present a pronounced seasonality, with more than $80 \%$ of the annual precipitation falling during summer (June to September). Average monthly temperatures have an annual amplitude of approximately $12^{\circ} \mathrm{C}$ at every meteorological station.

The station data demonstrate that the region is clearly under the influence of the Indian monsoon system (e.g. Webster et al., 1998; Wang, 2006). During the Indian summer monsoon, moisture originating from the Bay of Bengal moves to the north and northwest and initiates heavy orographic rainfall when colliding with the mountain front of eastern and central Himalaya (e.g. Bookhagen and Burbank, 2006). In winter, the overall monsoon-related circulation weakens allowing the westerly upper-tropospheric synoptic-scale waves, dry over Nepal, to be dominant (e.g. Wang, 2006). The central Himalaya is characterised by a two-step topography triggering two rainfall peaks, the outer peak occurring along the southern Himalayan foothills ( $\sim 900 \mathrm{~m}$ a.s.l.) and the inner peak along the southern flanks of the Greater Himalaya ( 2100 m a.s.l.) (Bookhagen and Burbank, 2006, 2010; Shrestha et al., 2012). The glaciers surveyed in this 


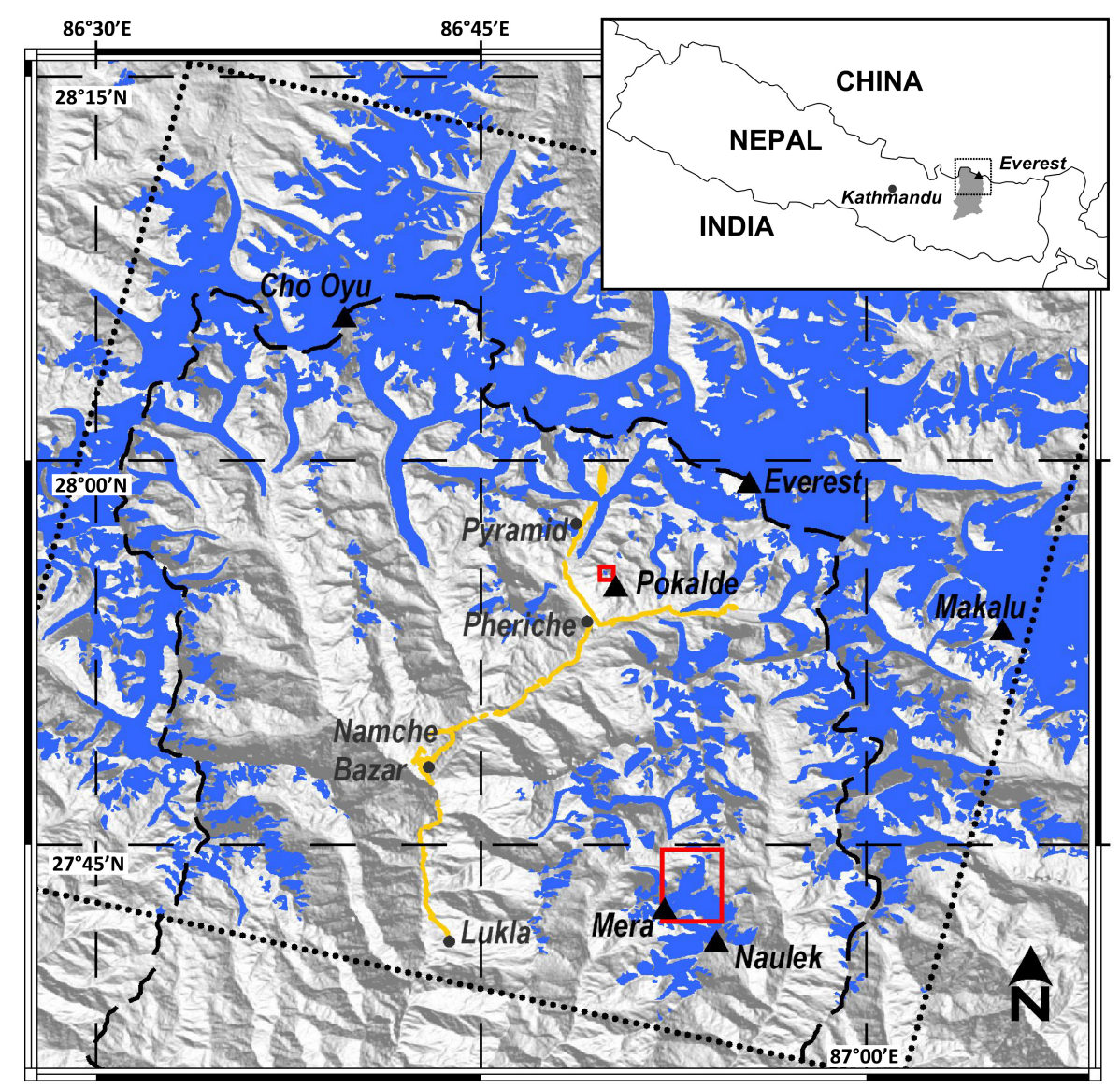

Fig. 1. Map of the high Dudh Koshi basin (in grey in the inset map of Nepal and with limits represented by the dashed black line in the main map) where Mera and Pokalde glaciers are located (inside the red squares). Meteorological stations and main summits are indicated by dots and triangles respectively. Glacierized areas from the Randolph Glacier Inventory v2.0 (Arendt et al., 2012) are represented in blue. The dotted line locates the footprint of the SPOT5-HRG image. In orange, a kinematic DGPS survey performed in April 2011 along the trail of the Everest Base Camp.

study are located just beyond this inner rainfall peak, and are submitted to a strong south-to-north negative gradient of precipitation. This is illustrated by the decreasing amount of precipitation received by meteorological stations that are located higher in elevation and closer to the Tibetan Plateau (Figs. 1 and 4).

\section{Methodology}

\subsection{Mass balance}

Since 2007 and 2009, annual mass balance measurements have been carried out on Mera and Pokalde glaciers respectively. For practical reasons, measurements are performed each year in November on Mera Glacier or between the end of October and the beginning of December on Pokalde Glacier. It would have been more appropriate to systematically carry out field trips at the end of the melt season (i.e. beginning of October), but considering that neither ablation nor accumulation are significant between mid-October and mid-December on Nepalese glaciers (see Sect. 5.2), selecting this period for field measurements does not have significant impact on the determination of annual and seasonal mass balances. Extra stake readings have been performed in April 2009 and April 2013 on Mera Glacier, and every 2 to 5 months on Pokalde Glacier. The direct glaciological method is used for these measurements (Cuffey and Paterson, 2010).

In the ablation area, annual mass balance is determined from bamboo stakes inserted up to $10 \mathrm{~m}$ deep in the ice. In the mass balance calculations, ice density is assumed to be $900 \mathrm{~kg} \mathrm{~m}^{-3}$, and in the presence of snow, its density is measured in the field. Snow densities are not very spatially or temporally variable with average values of $370 \mathrm{~kg} \mathrm{~m}^{-3}$ (standard deviation of $30 \mathrm{~kg} \mathrm{~m}^{-3}$ ) below $5600 \mathrm{~m}$ a.s.l. The number of ablation stakes has progressively increased on Mera Glacier from 28 in 2007 to 45 stakes in 2012, and all stakes are located between 5000 and $5550 \mathrm{~m}$ a.s.l. (Fig. 2). Five 


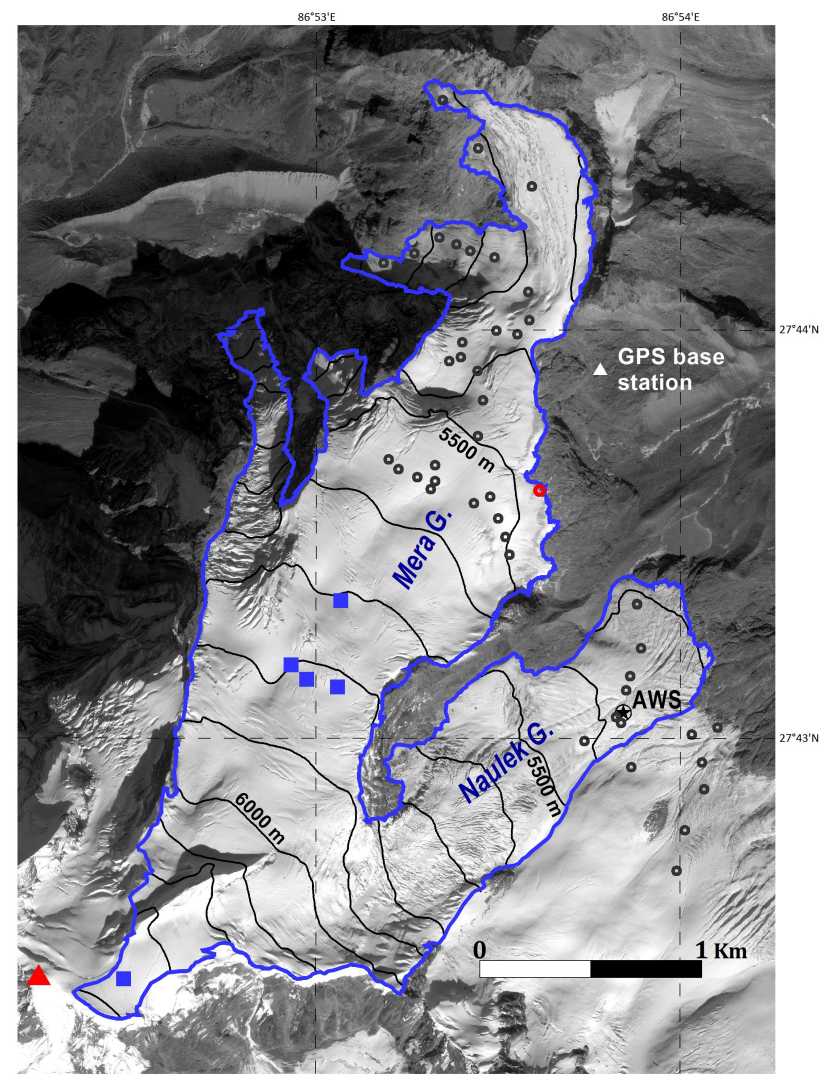

Fig. 2. Map of Mera Glacier, showing the network of ablation stakes (grey circles and one peculiar stake highlighted in red, see text for details), the accumulation measurement sites (blue squares) and the Mera automatic weather station (AWS - black star). From the Mera central summit (red triangle), Mera Glacier flows toward the north and splits into two main branches, referred as Mera and Naulek branches respectively. Background: Pleiades-1A image of 25 November 2012 (CNES 2012/Distribution Astrium).

stakes have been inserted on Pokalde Glacier in 2009 between 5500 and $5600 \mathrm{~m}$ a.s.l. (Fig. 3).

In the accumulation area above $5600 \mathrm{~m}$ a.s.1., 6 cores $(5$ on Mera Glacier, 1 on Pokalde Glacier) are drilled to measure the annual net accumulation from snow layering (stratigraphy) and density measurements. Snow densities ranged from a mean of $380 \mathrm{~kg} \mathrm{~m}^{-3}$ (standard deviation of $30 \mathrm{~kg} \mathrm{~m}^{-3}$ ) at $5700-5800 \mathrm{~m}$ a.s.l. to $450 \mathrm{~kg} \mathrm{~m}^{-3}$ (standard deviation of $10 \mathrm{~kg} \mathrm{~m}^{-3}$ ) at $\sim 6330 \mathrm{~m}$ a.s.l. Recco avalanche reflectors systematically tied to $3 \mathrm{~m}$ long bamboo accumulation stakes and blue-coloured chalk powder spread out over a $2 \mathrm{~m}^{2}$ surface mark an annual horizon. This horizon is then located easily the following year thanks to the Recco detector, and the previous annual surface is identified while drilling. During years of high accumulation, ablation stakes at $\sim 5500 \mathrm{~m}$ a.s.l. also serve as accumulation stakes and conversely, when ablation is strong, accumulation stakes are used to measure ablation.

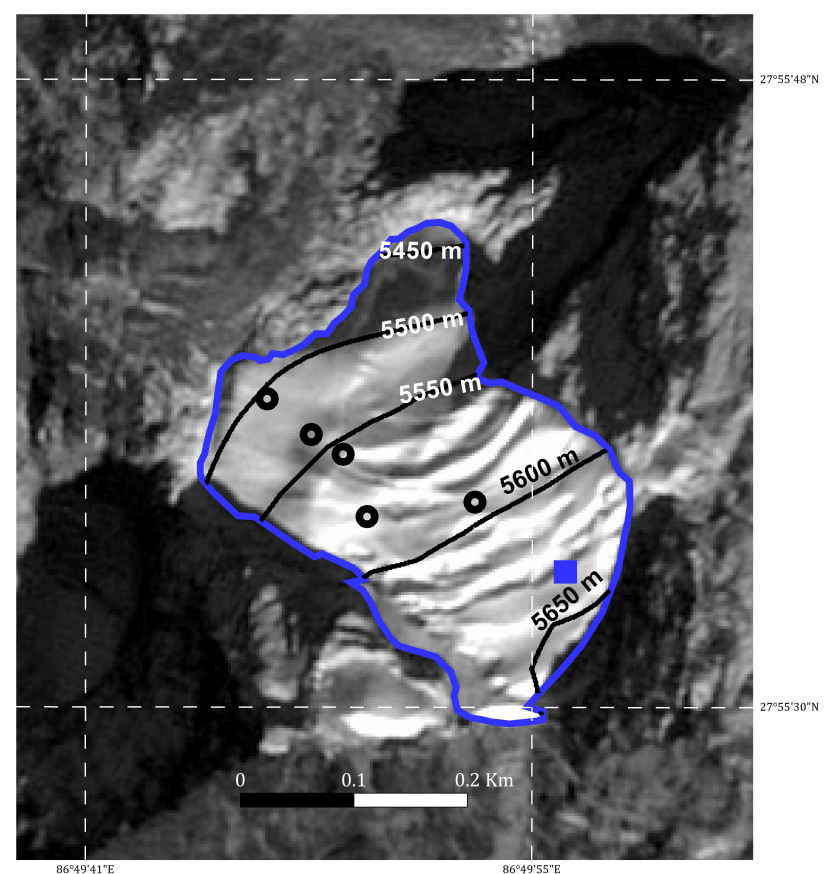

Fig. 3. Maps of Pokalde Glacier, showing the network of ablation stakes (grey circles), the accumulation measurement site (blue square). Background: SPOT5 image of 4 January 2011 (CNES 2011/Distribution Astrium).

Stakes are sometimes lost, buried under snow or broken by wind or climbers but our observation network allowed for a minimum of 17 point mass balance measurements in 2011-2012 (reading of 14 ablation stakes and 3 accumulation measurements performed) to a maximum of 31 in 2008-2009 (reading of 27 ablation stakes and 4 accumulation measurements performed). Ablation measured at stakes located on Naulek Glacier outside the Naulek branch of Mera Glacier are consistent with ablation measured at the Naulek branch stakes (inserted on similar slopes with same aspect, Fig. 2). Those stakes have thus been included in the mass balance calculations to increase the number of ablation measurements especially during years where this number was low (i.e. 2009-2010 and 2010-2011).

The annual glacier-wide mass balance $B_{\mathrm{a}}$ is calculated according to:

$B_{\mathrm{a}}=\frac{1}{s} \int_{s} b_{\mathrm{a}} \mathrm{d} s \quad$ (in m w.e.)

where $B_{\mathrm{a}}$ is the point surface mass balance obtained from the corresponding stake readings or net accumulation measurements and $S$ is the glacier area. The hypsography of every glacier is extracted from digital elevation models (DEMs) derived from Pleiades stereo-images of 25 November 2012 for Mera Glacier and from SPOT5-HRS stereo-images of 4 January 2011 for Pokalde Glacier (see Sect. 4.4). The glaciers were delineated by visual inspection of the images with the 

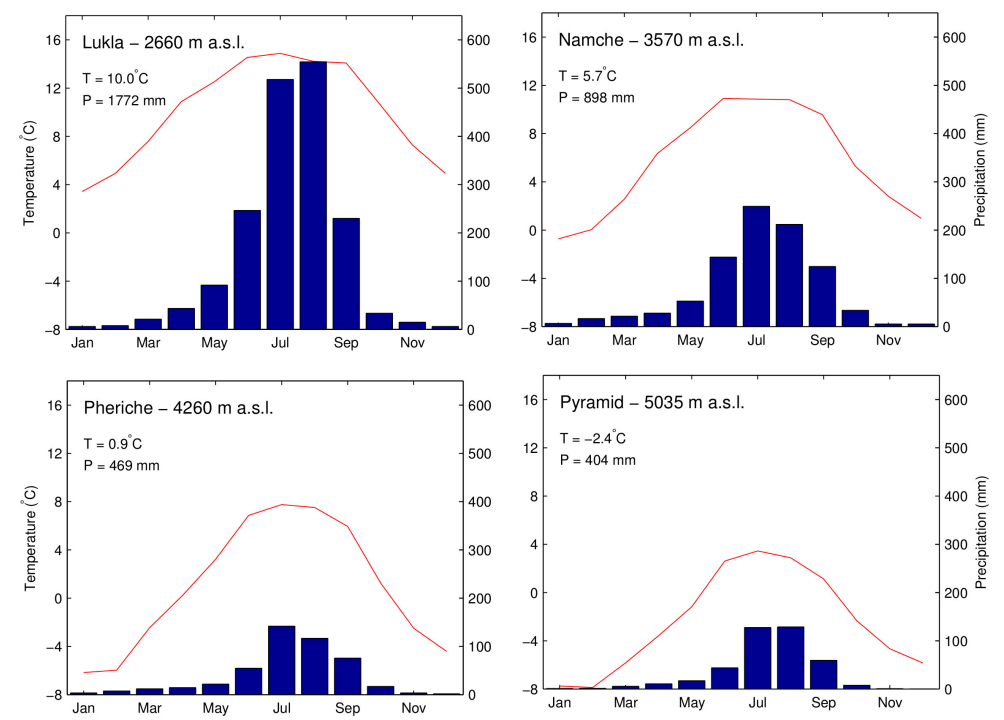

Fig. 4. Mean annual cycle of monthly precipitation ( $P$, histograms) and monthly air temperature $(T$, red line) during $2003-2012$ at four meteorological stations operated by Ev-K2-CNR: Lukla (2660 m a.s.1.), Namche Bazar (3570 m a.s.1.), Pheriche (4260 m a.s.1.) and Pyramid (5035 m a.s.1.). $T$ and $P$ are the mean annual temperature and the cumulative annual precipitation respectively. The data gaps for Lukla station are April to September 2004, July, September and October 2006, June to September 2008, March to September 2010, August, September and December 2011, January to March 2012 (only for precipitation) April, May and October to December 2012. The data gaps for Namche Bazar station are April to June 2004, September and October 2006, September and October 2007, June to October 2009, March to September 2010, April, May and October to December 2012. The data gaps for Pheriche station are April to June 2004, June to October 2008 (only for precipitation), January to April and June 2009, April and May 2011, November 2011 to June 2012. The data gaps for Pyramid station are April to June 2004, May to September 2006 (only for precipitation), November 2008, May to October 2009 (only for precipitation), June and July 2010 (only for precipitation) October to December 2010, January and June 2011, November and December 2011 (only for temperature), January and October to December 2012.

aid of field photographs. Using a single map over the whole measuring period to derive $B_{\mathrm{a}}$ means that we obtain here the reference-surface glacier-wide balance (Harrison et al., 2005).

On the small Pokalde Glacier, mass balance was obtained for every $10 \mathrm{~m}$ altitudinal range using a single linear fit of all available in-situ $B_{\mathrm{a}}$ measurements (ablation and accumulation) versus elevation. Every $10 \mathrm{~m}$ altitudinal range area was then multiplied by its corresponding mass balance, summed over the entire glacier and finally divided by the glacier area $S$ to get the glacier-wide mass balance (Eq. 1). On the larger Mera Glacier, $B_{\mathrm{a}}$ was calculated in a similar way but using distinct linear interpolations for the ablation and accumulation zones. In the ablation zone, Mera and Naulek branches were also considered separately because they have fairly distinct mass balance gradients. We consider that the single measurement performed at $\sim 6330 \mathrm{~m}$ a.s.l. is representative of the uppermost net accumulation in the drainage basins of both Mera and Naulek branches. Figure 5 displays for every surveyed year the regression lines that have been used to derive the glacier-wide mass balance. Each year, the equilibrium-line altitude (ELA) is deduced as the altitude at which the regression line crosses the zero mass balance value.
Accuracy of this overall specific annual mass balance depends on various factors related to (i) the measurements themselves (such as the errors in stake readings or density measurements), and to (ii) the density and representativeness of stakes or accumulation measurement sites (i.e. the sampling error). As in Thibert et al. (2008), on Mera Glacier, we conducted an uncertainty analysis separating the error related to the measurements (standard deviation of $0.08 \mathrm{~m}$ w.e. $\mathrm{yr}^{-1}$ ) and the sampling error (standard deviation ranging from 0.21 to $0.29 \mathrm{~m}$ w.e. $\mathrm{yr}^{-1}$, according to the number of measurement sites from 31 (2008-2009) to 17 (2011-2012), respectively). Averaging those errors over the glacier surface and over the studied period, we obtained a mean overall uncertainty of $\pm 0.28 \mathrm{~m}$ w.e. $\mathrm{yr}^{-1}$ for the glacier-wide mass balance. Zemp et al. (2009) provided also an interesting discussion examining the mass balance error, and concluded that the confidence interval for the global mass-balance dataset is in the magnitude of two standard errors of the reported annual mass-balance data, i.e. between 0.25 to $0.5 \mathrm{~m}$ w.e. As recommended by Thibert et al. (2008) or Zemp et al. (2013), to check the representativeness of our stake network and detect potential systematic biases, in the future, we will validate mass balances derived from annual field observations with decadal volume changes assessed from geodetic methods. 

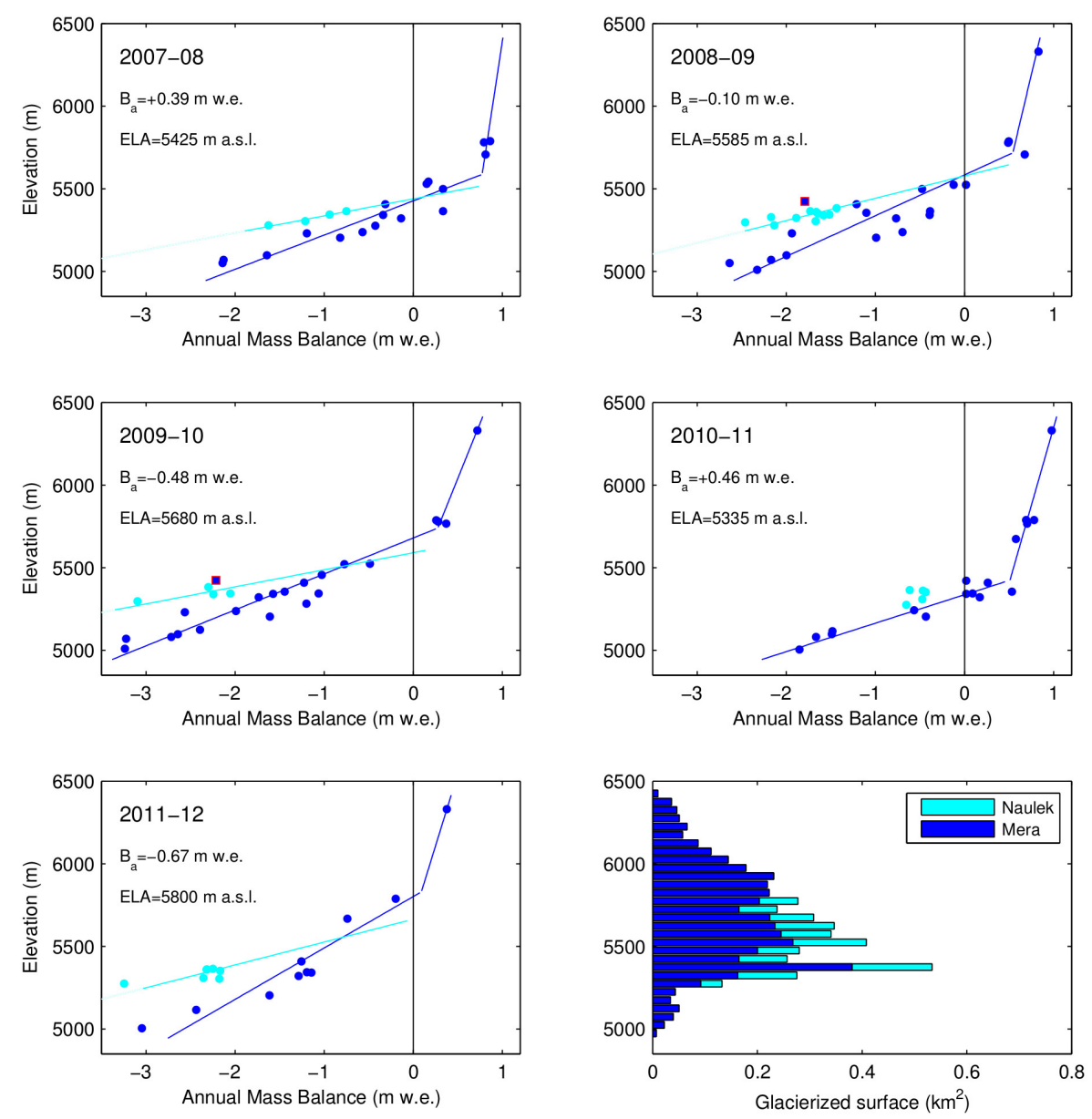

Fig. 5. Five first panels: five years of annual point mass balance (dots) as a function of altitude derived from field measurements (stakes, drillings or pits) on Mera Glacier. Measurements were performed on 17 November 2007, 6 November 2008, 5 November 2009, 11 November 2010, 10 November 2011 and 23 November 2012 \pm 4 days. Dark blue is used for the Mera branch, light blue for Naulek. The measurement on Mera in 2008-2009 and 2009-2010 displayed as a blue square highlighted with a red contour refer to the same stake facing northeast. Also shown are the linear regression lines used to derive the annual glacier-wide mass balance $B_{\mathrm{a}}$ (point mass-balance measurements above (below) $5600 \mathrm{~m}$ a.s.l. are used to derive the mass balance gradient over the accumulation (ablation) area except in 2011-2012). In 2010-2011, there were not enough measurements on Naulek branch to derive a significant regression line, and therefore the mean vertical mass balance gradient obtained over the four other years on Naulek was used instead, i.e. $0.85 \mathrm{~m}$ w.e. $(100 \mathrm{~m})^{-1}$. In $2011-2012$, point mass balance data measured at 5790 and $5670 \mathrm{~m}$ a.s.l. were exceptionally negative and thus used to derive the linear regression line over the ablation area, the upper regression line being chosen equal to the mean vertical mass balance gradient obtained over the four previous years in the accumulation area, i.e. $0.06 \mathrm{~m}$ w.e. $(100 \mathrm{~m})^{-1}$. $B_{\mathrm{a}}$ and ELA for every year are displayed on the corresponding panel. Bottom right panel: hypsometry of Mera Glacier showing the respective areas of Naulek (light blue) and Mera (dark blue) branches.

Despite the relatively large error bars, year-to-year relative differences are instructive for climatic purposes because annual values refer to the same map, to the same area-elevation distribution function and to the same measurement network.

\subsection{Surface velocity}

Annual surface ice velocities have been measured every year in November on Mera Glacier by determining the displacement of 47 stakes (45 ablation stakes and 2 accumulation stakes) using a Differential Global Positioning System (DGPS) (Topcon devices, dual frequency, $1 \mathrm{~s}$ acquisition fre- quency, $\sim 30 \mathrm{~s}$ acquisition time at every stake). These measurements have been performed relative to a fixed reference point outside the glacier on firm rocks (Fig. 1). The accuracy of DGPS measurements depends on the number of operating satellites, their geometrical configuration in the sky, the distance to the DGPS base station and the acquisition frequency and duration; maximum uncertainty is $\pm 0.1 \mathrm{~m}$ for horizontal and vertical components, the horizontal uncertainty being usually lower. The accuracy in $x$ (easting), $y$ (northing) and $z$ (elevation) of each stake position is estimated at $\pm 0.2 \mathrm{~m}$ depending thus mainly on the size of the hole in which the 
stake has been set up. As a consequence the surface ice velocities measured from stake displacements have an accuracy of $\pm 0.3 \mathrm{~m} \mathrm{yr}^{-1}$.

\subsection{Glacier thickness}

Ground penetrating radar measurements have been conducted in November 2009 and November 2012 on Mera Glacier in order to determine ice thickness on 2 transverse cross sections at 5350 and $5520 \mathrm{~m}$ a.s.l. as well as close to the top of the glacier at $6350 \mathrm{~m}$ a.s.l. The radar system is made up of a transmitter and a receiver, each of which is outfitted with a similar kind of antenna (Hubbard and Glasser, 2005). In our study, we used the pulse radar transmitter (Icefield Instruments, Canada) based on the Narod transmitter (Narod and Clarke, 1994). The radar survey was carried out at a frequency of $4.2 \mathrm{MHz}$ with antenna length of $10 \mathrm{~m}$. Transmitter and receiver were put in snow sledges, separated by a fixed distance of $20 \mathrm{~m}$ and moved together along the profiles with a measurement every $10 \mathrm{~m}$. The positions of the receiver and the transmitter are known through DGPS measurements, with an accuracy of $\pm 0.1 \mathrm{~m}$. The speed of electromagnetic wave propagation in ice has been assumed to be $167 \mathrm{~m} \mathrm{ss}^{-1}$ (Hubbard and Glasser, 2005).

The surface of the bedrock was constructed as an envelope of all ellipse functions, which give all the possible reflection positions between sending and receiving antennae. Reflections are not considered to come from the point perpendicular beneath the antennae but from the bedrock point nearest to the instrument. Estimates of bedrock depths were then migrated and interpolated to reconstruct the glacier/bedrock interface in two dimensions. In this way, we account for the bed slope. See Azam at al. (2012) for details of the methodology and an example of a radargram acquired on Chhota Shigri Glacier (India) using the same device.

\subsection{Digital elevation models}

A $4 \mathrm{~m}$ DEM of Mera Glacier was derived from a stereopair of high resolution $(0.7 \mathrm{~m})$ Pleiades-1A images acquired 25 November 2012. Pleiades-1A is the first member of a new family of high resolution satellite from the French Space Agency (CNES) and was launched on 17 December 2011 (http://smsc.cnes.fr/PLEIADES/). To our knowledge, we present here the first DEM derived from Pleiades-1A imagery over a glaciated region. Given the lack of accurate field ground control points (GCPs), GCPs were generated from SPOT5 images and a SPOT5 DEM that were first corrected using DGPS measurements performed in the Khumbu valley.

Our reference dataset is a $40 \mathrm{~m} \mathrm{DEM}$ and a co-registered $5 \mathrm{~m}$ ortho-image computed without GCPs by the French Mapping Institute (IGN, National Institute of Geographic and Forest Information) from SPOT5-HRS images acquired 4 January 2011 (Korona et al., 2009; Gardelle et al., 2013). This regional $(120 \mathrm{~km}$ by $120 \mathrm{~km})$ but relatively coarse dataset is used as reference to ortho-rectify a $2.5 \mathrm{~m}$ SPOT5HRG image ( $60 \mathrm{~km}$ by $60 \mathrm{~km}$, see footprint in Fig. 1) acquired 29 October 2009. A sub-pixel co-registration was achieved using the Cosi-Corr software (Leprince et al., 2007). Approximately 3600 kinematic DGPS measurements, acquired along the trails of the Everest base camp (Khumbu Valley, see location in Fig. 1) in April 2011, were overlaid on the SPOT5-HRG image and the image was shifted westward by $10 \mathrm{~m}$ so that the trails, clearly visible on the $2.5 \mathrm{~m}$ image, matched the location of the DGPS tracks. The $10 \mathrm{~m}$ westward shift was also applied to the SPOT5-HRS $40 \mathrm{~m}$ DEM. After this horizontal co-registration, the vertical difference between the SPOT5-HRS DEM and the altitude of the kinematic DGPS points was computed. As the difference was very close to zero (mean $=0.7 \mathrm{~m}$, median $=0.1 \mathrm{~m}$; standard deviation $=7.6 \mathrm{~m} ; N=3590$ ), the SPOT5-HRS DEM was not shifted vertically.

The $2.5 \mathrm{~m}$ SPOT5-HRG ortho-image and the $40 \mathrm{~m}$ SPOT5HRS DEM, now both co-registered to the DGPS data, were used to identify 25 GCPs for Pleiades raw images. This set of GCPs was then ingested in the ${ }^{\odot}$ PCI Geomatica software (version 2013) to compute the DEM. The root-mean-square (RMS) residuals for those 25 GCPs were $1.36 \mathrm{~m}$ and $1.24 \mathrm{~m}$ for the Easting and Northing map projection coordinates, about twice the pixel size of the Pleiades images and half the pixel size of the SPOT5-HRG image. The accuracy of the final $4 \mathrm{~m}$ DEM was checked against DGPS measurements performed on Mera Glacier between 20 and 27 November 2012, within a few days of the acquisition of the Pleiades-1A stereo pair. Horizontal and vertical precision of the DGPS measurements on Mera Glacier are estimated to $0.1 \mathrm{~m}$. For a total of 445 points, the mean and median of the elevation difference between the Pleiades DEM and the DGPS are identical, at $-0.93 \mathrm{~m}$, and the standard deviation is $1.02 \mathrm{~m}$. The $0.93 \mathrm{~m}$ mean vertical shift was added to all altitudes in the Pleiades DEM.

\section{Results}

\subsection{Annual and cumulative glacier-wide mass balance}

The annual glacier-wide mass balances $B_{\mathrm{a}}$ for Mera and Pokalde glaciers are reported in Table 2, for the periods 2007-2012 and 2009-2012 respectively. Figure 6 displays the annual and cumulative mass balances for these glaciers. On Mera Glacier, the inter-annual variability is large (standard deviation of $\pm 0.51 \mathrm{mw}$.e. $\mathrm{yr}^{-1}$ ) with 2 positive years (2007-2008 and 2010-2011), 2 negative years (2008-2009 and 2011-2012) and a balanced year (2008-2009). Mera Glacier experienced balanced or slightly negative mass balance conditions between 2007 and 2012 (mean $B_{\mathrm{a}}=-0.08 \pm 0.28 \mathrm{~m}$ w.e. $\mathrm{yr}^{-1}$ ) while the mass loss for Pokalde Glacier was more pronounced (mean $B_{\mathrm{a}}=-0.72 \pm 0.28 \mathrm{~m}$ w.e. $\mathrm{yr}^{-1}$ compared to 
$-0.23 \pm 0.28 \mathrm{~m}$ w.e. $\mathrm{yr}^{-1}$ for Mera Glacier between 2009 and 2012). Over the period 2009-2012, the cumulative mass balance difference between both glaciers is $1.46 \mathrm{~m}$ w.e., with Pokalde Glacier losing mass more rapidly than Mera Glacier. On Mera Glacier the ELA varied from a minimum of $5335 \mathrm{~m}$ a.s.l. in $2010-2011 \quad\left(B_{\mathrm{a}}=0.46 \pm 0.28 \mathrm{~m}\right.$ w.e.; $\mathrm{AAR}=0.89)$ to a maximum of $5800 \mathrm{~m}$ a.s.l. in 2011-2012 $\left(B_{\mathrm{a}}=-0.67 \pm 0.28\right.$ m w.e.; $\left.\mathrm{AAR}=0.29\right)$.

\subsection{Seasonal glacier-wide mass balance}

On 23-25 April 2009, stake readings were performed on Mera Glacier from the snout to $5800 \mathrm{~m}$ a.s.l. to assess both winter and summer mass balances for the year 2008-2009 (Figs. 6 and 7a). In 2008-2009, the annual mass balance $(-0.10 \pm 0.28 \mathrm{~m}$ w.e. $)$ reveals that the glacier was close to steady state and some features of winter and summer mass balances can be pointed out. As expected, this Nepalese glacier is a summer-accumulation type glacier (Ageta and Fujita, 1996). In summer 2009, it experienced ablation below $5500 \mathrm{~m}$ a.s.l. and significant accumulation above resulting in positive summer mass balance (Fig. 6). Unexpectedly, ablation is non-negligible in winter between November 2008 and April 2009 at every elevation, which leads to negative winter mass balance (Fig. 6). Figure 7a gives the point mass balance as a function of elevation for the year 2008-2009, and also for the winter (6 November 2008-24 April 2009) and the summer (24 April 2009-5 November 2009) seasons. In winter, the glacier lost mass at every elevation, even in its highest parts, due to the combined effect of wind erosion and sublimation. The 2008-2009 glacier-wide winter mass balance is $-0.20 \mathrm{~m}$ w.e. In summer, the point mass balance as a function of elevation is very similar to the annual mass balance gradient, which means that the annual glacier-wide mass balance is almost exclusively controlled by the summer climatic conditions (Fig. 7a).

Additional stake readings were also performed on 16-21 April 2013, showing that the glacier-wide 2012-2013 winter mass balance (23 November 2012-18 April 2013) is not significantly different from zero (Fig. 6). Indeed point winter mass balance is very close to zero at all elevations (Fig. 7b) confirming that summer is the key season for the annual glacier mass balance. Snow occasionally deposited in winter is systematically blown away after some days, due to strong westerly winds (jet stream) that occur above $5000 \mathrm{~m}$ a.s.l. in this region (Wang, 2006). Snow accumulated in summer is likely to be less remobilized because it is often protected by a melt crust. At $6330 \mathrm{~m}$ a.s.1., since November 2008, we were unable to locate the blue horizon marker systematically spread over a $2 \mathrm{~m}^{2}$ area a few tenths of centimetres below the surface, and covered by dense snow in the previous year. However, we were able to recover the Recco reflector tied to a bamboo stake inserted deep enough to remain on-site. We assume that the snow surface at high elevations is systematically remobilized by wind, and then mostly sublimated in the

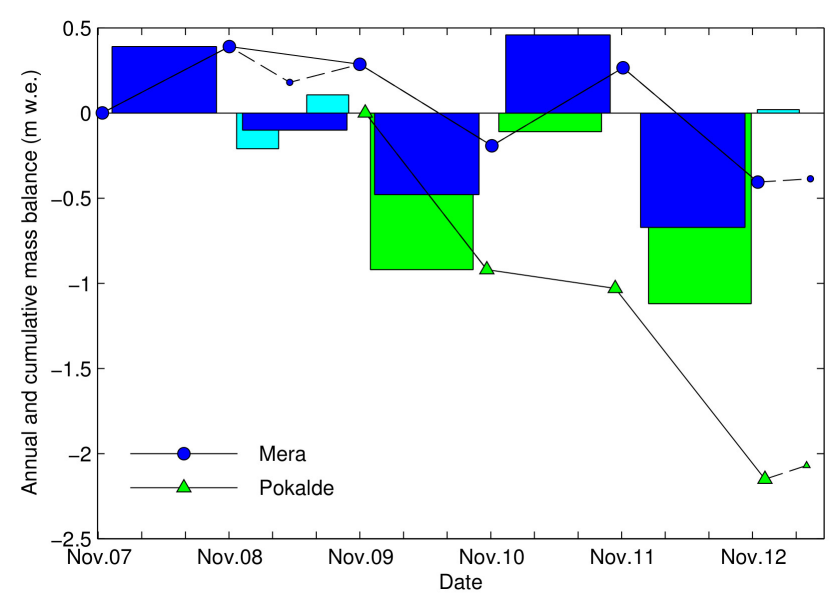

Fig. 6. Annual (dark blue and green large histograms) and cumulative (line with big blue dots and line with big green triangles) mass balances of Mera Glacier and Pokalde Glacier respectively. Also shown are the winter (November to April) and summer (April to November) mass balances for 2008-2009 and 2012-2013 (narrow cyan histograms - only Mera Glacier is represented) and the corresponding cumulative mass balances (dashed line with small blue dots for Mera Glacier and dashed line with small green triangles for Pokalde Glacier).

atmosphere or partly deposited again in wind-protected areas (eastern slopes). In November, during field trips, we sometimes experienced wind storms able to remobilize as much as 10 to $20 \mathrm{~cm}$ of surface snow in a few days. At the end of the winter (April), melting starts to occur in the lowest part of the ablation zone, and thus ablation is still greater in this part of the glacier than at higher elevations (Fig. 7a). In April 2013, we could not even find the blue horizons at the three accumulation measurement sites at $\sim 5800 \mathrm{~m}$ a.s.l., but accumulation stakes and Recco reflectors were still in place. During the 2012-2013 winter, ablation through wind erosion and sublimation was compensated by accumulation, leading to a mass balance of approximately zero at all elevations.

To ensure that 2008-2009 or 2012-2013 were not exceptional years and that other Nepalese glaciers also experience ablation or near-zero mass balance in winter, we analysed the regular measurements (typically every 2 to 5 months) available at the three lowest ablation stakes on Pokalde Glacier. Figure 8 shows the cumulative point mass balance recorded at these three stakes between November 2009 and September 2013. Ablation is obviously higher during the summer in this ablation zone but is also significant during the four winters surveyed here, with winter mass balances ranging from -0.1 to $-0.5 \mathrm{~m}$ w.e. at $5505 \mathrm{~m}$ a.s. 1 .

\subsection{Mass-balance gradients}

Figure 5 displays the annual point mass balances as a function of altitude for every year on Mera Glacier as well as the regression lines used to derive the mass-balance gradients 
Table 2. Annual and 5 yr mean glacier-wide mass balances $B_{\mathrm{a}}$, ELA, AAR and mass balance gradients db/dz for Mera and Pokalde glaciers, as well as some meteorological variables recorded at Pyramid Observatory (5035 ma.s.1.). On Mera Glacier, mass balance gradients are distinguished between Mera and Naulek branches (referred as Mera and Naulek subscripts). The standard deviation (STD) is also displayed for every variable. The error range for $B_{\mathrm{a}}$ is $\pm 0.28 \mathrm{~m}$ w.e. Also shown is the cumulative centred mass balance (cum. centred $B_{\mathrm{a}}=$ annual $B_{\mathrm{a}}$ - mean value of $B_{\mathrm{a}}$ over 2009-2012, the mean 2009-2012 value for Mera Glacier is $-0.23 \mathrm{~m}$ w.e. $\mathrm{yr}^{-1}$ ). When there are data gaps, meteorological variables at Pyramid have been reconstructed at monthly time-step over the 2003-2012 period, applying a regression equation with the corresponding variable recorded at Pheriche (4260 m a.s.1.) when available or otherwise at Namche Bazar (3570 m a.s.1.). Precipitation data are missing in 2008-2009.

\begin{tabular}{|c|c|c|c|c|c|c|c|}
\hline & $2007-08$ & $2008-09$ & $2009-10$ & $2010-11$ & $2011-12$ & Mean & STD \\
\hline & \multicolumn{7}{|c|}{ Mera Glacier } \\
\hline$B_{\mathrm{a}}$ (m w.e.) & 0.39 & -0.10 & -0.48 & 0.46 & -0.67 & -0.08 & 0.51 \\
\hline ELA (m) & 5425 & 5585 & 5680 & 5335 & 5800 & 5566 & 188 \\
\hline AAR & 0.74 & 0.55 & 0.42 & 0.89 & 0.29 & 0.58 & 0.24 \\
\hline $\mathrm{db} / \mathrm{dz}_{\text {Mera }}\left(\mathrm{m}\right.$ w.e. $\left.(100 \mathrm{~m})^{-1}\right)$ & 0.48 & 0.41 & 0.46 & 0.58 & 0.32 & 0.45 & 0.10 \\
\hline $\mathrm{db} / \mathrm{dz}_{\text {Naulek }}\left(\mathrm{m}\right.$ w.e. $\left.(100 \mathrm{~m})^{-1}\right)$ & 0.97 & 0.74 & 0.97 & - & 0.72 & 0.85 & 0.14 \\
\hline \multirow[t]{2}{*}{ Cum. centred $B_{\mathrm{a}}$ (m w.e.) } & & & -0.25 & 0.69 & -0.44 & - & - \\
\hline & \multicolumn{7}{|c|}{ Pokalde Glacier } \\
\hline$B_{\mathrm{a}}(\mathrm{m}$ w.e. $)$ & & & -0.92 & $-0.11^{\mathrm{a}}$ & -1.12 & -0.72 & 0.54 \\
\hline $\operatorname{ELA}(\mathrm{m})$ & & & 5625 & - & $>$ glacier & - & - \\
\hline AAR & & & 0.13 & - & 0 & - & - \\
\hline $\mathrm{db} / \mathrm{dz}\left(\mathrm{m}\right.$ w.e. $\left.(100 \mathrm{~m})^{-1}\right)$ & & & 1.65 & - & 1.37 & 1.51 & - \\
\hline \multirow[t]{2}{*}{ Cum. centred $B_{\mathrm{a}}$ (m w.e.) } & & & -0.20 & 0.61 & -0.40 & - & - \\
\hline & \multicolumn{7}{|c|}{ Meteorological conditions at Pyramid (5035 m a.s.1.) } \\
\hline Annual temperature $\left({ }^{\circ} \mathrm{C}\right)$ & -2.6 & -1.7 & -2.3 & -2.9 & -2.8 & -2.5 & 0.5 \\
\hline Summer ${ }^{\mathrm{b}}$ temperature $\left({ }^{\circ} \mathrm{C}\right)$ & 2.4 & 2.7 & 0.7 & 2.4 & 3.1 & 2.3 & 0.9 \\
\hline Winter ${ }^{\mathrm{c}}$ temperature $\left({ }^{\circ} \mathrm{C}\right)$ & -5.2 & -4.0 & -3.9 & -5.5 & -5.8 & -4.9 & 0.9 \\
\hline Annual precipitation (mm) & 391 & - & 343 & 447 & 374 & 389 & 44 \\
\hline Summer ${ }^{b}$ precipitation $(\mathrm{mm})$ & 372 & - & 295 & 409 & 330 & 352 & 50 \\
\hline Winter $^{\mathrm{c}}$ precipitation $(\mathrm{mm})$ & 19 & - & 48 & 38 & 44 & 37 & 13 \\
\hline
\end{tabular}

$(\mathrm{db} / \mathrm{dz})$ for the accumulation area, and the ablation zones of Mera and Naulek branches. Annual db/dz on Naulek and Mera branches, and for Pokalde Glacier are also reported in Table 2. The mass-balance gradient on Mera branch is always lower than the one on Naulek branch, with respective mean values of 0.45 and $0.85 \mathrm{~m}$ w.e. $(100 \mathrm{~m})^{-1}$. Mass balance gradients are consistent from year to year, with standard deviations for Mera and Naulek branches of 0.10 and $0.14 \mathrm{~m}$ w.e. $(100 \mathrm{~m})^{-1}$, respectively. We believe that the systematic difference observed between Mera and Naulek branches comes from their orientation. Indeed, Naulek has a northeastern aspect, while Mera has an overall northerly aspect, with some elevations (5400-5500 ma.s.1.) facing northeast and the lowest elevations (below $5350 \mathrm{~m}$ a.s.l.) facing west. This variable aspect along Mera branch probably explains the larger scatter of point mass balance data around the regression line on Mera branch than on Naulek branch. In some cases, stakes on the northeast orientated part of Mera branch experience a net mass balance similar to that observed on Naulek branch (see in particular one point mass balance measurement of Mera above the Naulek regression line, in
2008-2009 and 2009-2010; highlighted with a red square in Fig. 5). The vertical mass balance gradient difference observed between both branches also partly explains why the terminus of Naulek (5260 m a.s.1.) is located at higher elevation than the terminus of Mera (4940 m a.s.1.).

Pokalde Glacier has a northwest aspect but its massbalance gradient $\left(1.51 \mathrm{~m}\right.$ w.e. $(100 \mathrm{~m})^{-1}$, Table 2$)$ is double to triple that observed on both branches of Mera Glacier. Three reasons may explain this difference: (i) the glacier is much smaller than Mera Glacier, and thus likely experiences enhanced long-wave radiation and heat advection from the surrounding terrain that contribute to enhanced melting (e.g. Olyphant, 1986; Wagnon et al., 2009); (ii) it is located inside the mountain range and thus submitted to a much drier climate than Mera Glacier. The 5500-5630 m a.s.1. area where measurements are performed is often partly covered by snow, and partly by exposed ice enhancing short-wave radiation absorption. The fact that the altitudinal range considered here often encompasses the snow-ice transition zone explains why the mass-balance gradient is steepened; (iii) the vertical mass balance gradient of Pokalde Glacier is likely to be more 

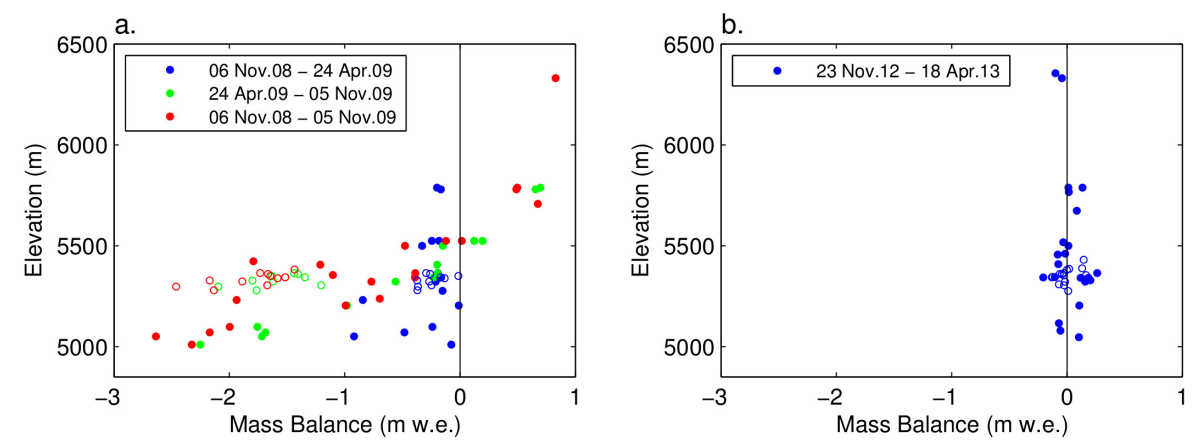

Fig. 7. (a) Point mass balance as a function of elevation, for the entire 2008-2009 year (red dots), for the winter season (blue dots) and for the summer season (green dots). Plain and open dots refer to Mera and Naulek branches, respectively. (b) Same as (a) but only for the winter season 2012-2013.

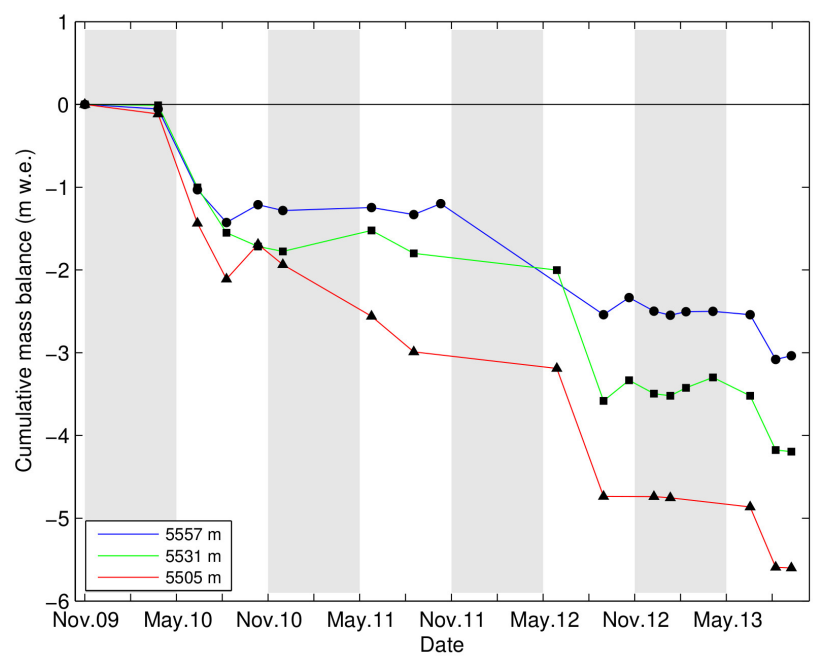

Fig. 8. Cumulative point mass balance recorded at the three lowest stakes (5505 - triangles, 5531 - squares and $5557 \mathrm{~m}$ a.s.1. - dots) between November 2009 and September 2013 on Pokalde Glacier (lines). Grey areas highlight the main winter season (from November to April).

uncertain than that on Mera Glacier due to its narrow elevation range and the reduced number of stakes (only $130 \mathrm{~m}$ altitude difference between the lowest and the highest stakes). Differences in aridity and size between Mera and Pokalde glaciers are also responsible for the altitudinal mass-balance difference observed on stakes. For instance, the ablation measured at $5550 \mathrm{~m}$ a.s.l. on Pokalde Glacier is equivalent to the ablation measured $200 \mathrm{~m}$ lower on Mera Glacier.

\subsection{Mean annual surface velocities}

Mean annual surface velocity measurements are located on the map of Mera Glacier (Fig. 9). Over the period 20072012, no velocity change was detectable, in agreement with balanced conditions over this relatively short time period.
Measured surface velocities are low, and vary with elevation: $5 \mathrm{~m} \mathrm{yr}^{-1}$ at $6330 \mathrm{~m}$ a.s.1., $14 \mathrm{~m} \mathrm{yr}^{-1}$ at $5780 \mathrm{~m}$ a.s.1., $6 \mathrm{~m} \mathrm{yr}^{-1}$ at 5550 , and $1 \mathrm{~m} \mathrm{yr}^{-1}$ below $5350 \mathrm{~m}$ a.s.l. on Mera branch. On Naulek, velocities remain low at around $3 \mathrm{~m} \mathrm{yr}^{-1}$ (below $5550 \mathrm{~m}$ a.s.1.). These low velocities are coherent with the reduced slope (mean slope $=16^{\circ}$ ) and low thickness of this glacier (see Sect. 5.5) as well as the limited net accumulation measured on the glacier (from a minimum of $0.38 \mathrm{~m}$ w.e. in 2011-2012 to a maximum of 0.98 mw.e. in 2010-2011 at $6330 \mathrm{~m}$ a.s.l.). Additionally, the glacier may be cold-based, which helps explain the low surface velocities. We do not have any firm confirmation of this feature but in 2010, we performed a shallow drilling at $6350 \mathrm{~m}$ a.s.l. and measured an ice temperature of $-5.7^{\circ} \mathrm{C}$ below the active layer at $20 \mathrm{~m}$ deep. Given that the glacier is only $55 \mathrm{~m}$ thick at this elevation (see Sect. 5.5) and that the basal flux does not probably exceed $0.1 \mathrm{~W} \mathrm{~m}^{-2}$ (Zhang et al., 2013 estimate a value of $0.02 \mathrm{~W} \mathrm{~m}^{-2}$ below East Rongbuk Glacier in Everest area), the glacier is likely to be entirely cold at this elevation.

\subsection{Ice thicknesses and cross section areas}

The cross section obtained from GPR measurements at $5350 \mathrm{~m}$ a.s.l. (referred hereafter as CS_5350) performed in November 2009 shows a maximum ice thickness larger than $100 \mathrm{~m}$ on the left side of the glacier (Fig. 10). Given that the ice flow velocities in this region are much higher than velocities measured on the right side (Fig. 9), this area corresponds to the main ice stream. The cross section area at $5350 \mathrm{~m}$ a.s.l. is $42400 \mathrm{~m}^{2}$. The cross section obtained from GPR measurements at $5520 \mathrm{~m}$ a.s.l. (referred hereafter as CS_5520) reveals an irregular profile with a valley between two main subglacial ridges. The maximum thickness is close to $95 \mathrm{~m}$ at the centre of the valley (Fig. 10). The ice thickness remains unknown on the last $200 \mathrm{~m}$ of the left side of this cross section due to the crevasses and dangerous access. Interpolating linearly to fill this gap between the last measurement point and the glacier margin, the cross section at $5520 \mathrm{~m}$ a.s.l. is estimated at $61600 \mathrm{~m}^{2}$. Two additional short profiles about 


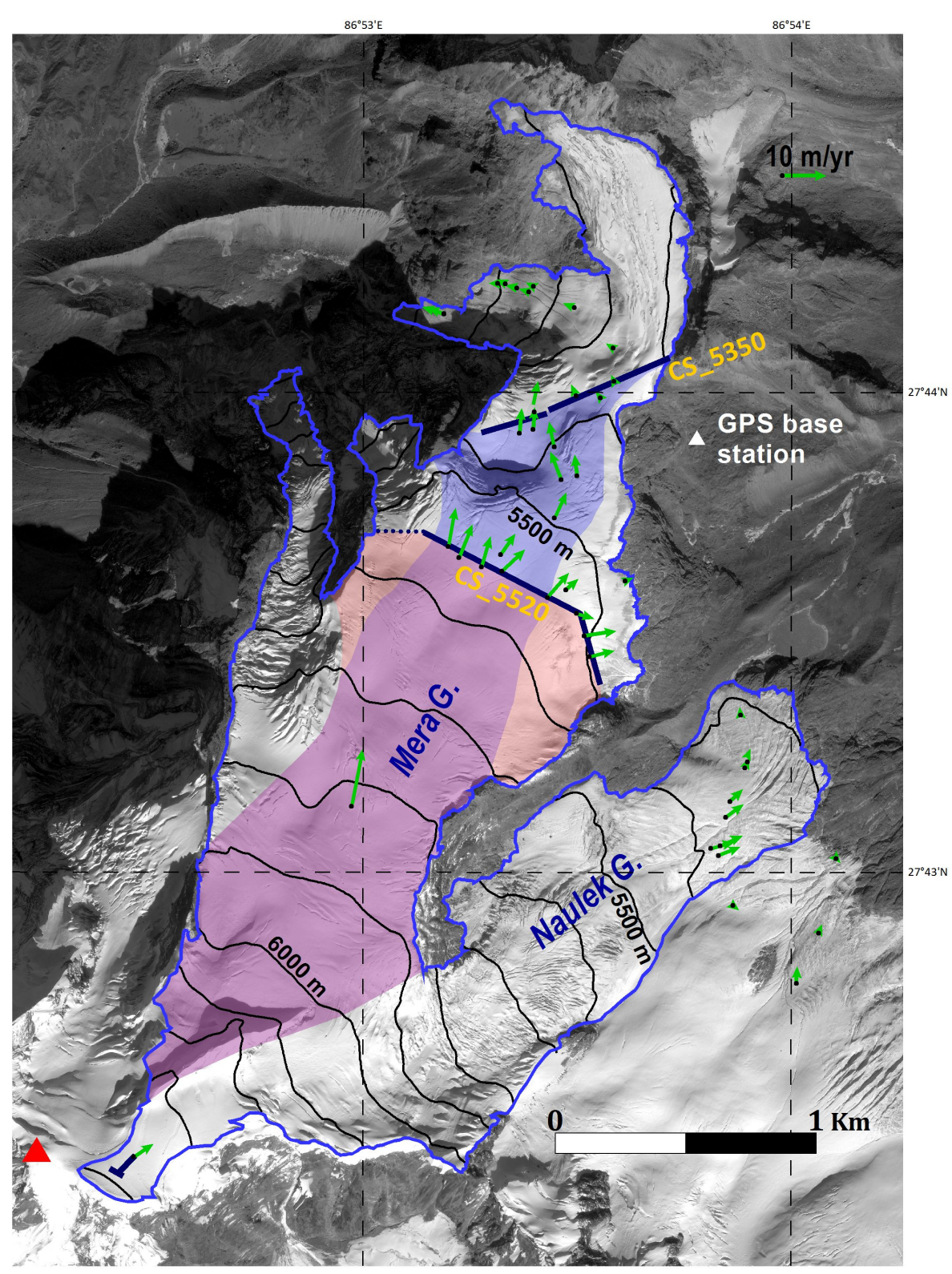

Fig. 9. Map of Mera Glacier showing mean annual surface velocities measured during the period 2007-2012 (green vectors). All DGPS measurements have been averaged, and the number of measuring years used to obtain annual velocities varies from 1 (1 single year of measurements) to 5 (the full period), depending on the survival time of the stakes. The blue line is the glacier outline, and the dark blue short segments are GPR survey cross sections that have been measured in the field in November 2009 (CS_5520 and CS_5350 at 5520 and $5350 \mathrm{~m}$ a.s.1. respectively) and in November 2012 (at $6350 \mathrm{~m}$ a.s.1.). The dashed part of CS_5520 on the left bank of the glacier corresponds to the unsurveyed interpolated part of the section. Transparent blue and pink areas are the areas feeding CS_5350 and CS_5520 respectively (with a mixed purple colour when these areas are overlapping). Background: 25 November 2012 Pleiades-1A image (CNES 2012/Distribution Astrium).

$100 \mathrm{~m}$ long (transverse and longitudinal cross sections) carried out at $6350 \mathrm{~m}$ a.s.l. show an ice thickness of about $55 \mathrm{~m}$. The accuracy of the calculated ice thickness is determined, in part, by the accuracy of the measurement of the time delays and the antenna spacing. Thanks to clear reflections, interface geometry was generally easy to determine on all pro- files. Additional errors may arise because the smooth envelope of the reflection ellipses is only a minimal profile for a narrow, deep valley-shape bed topography, with the result that the ellipse equation will be governed by an arrival from a reflector located toward the side and thus not directly beneath the point of observation. Further errors may be introduced by 


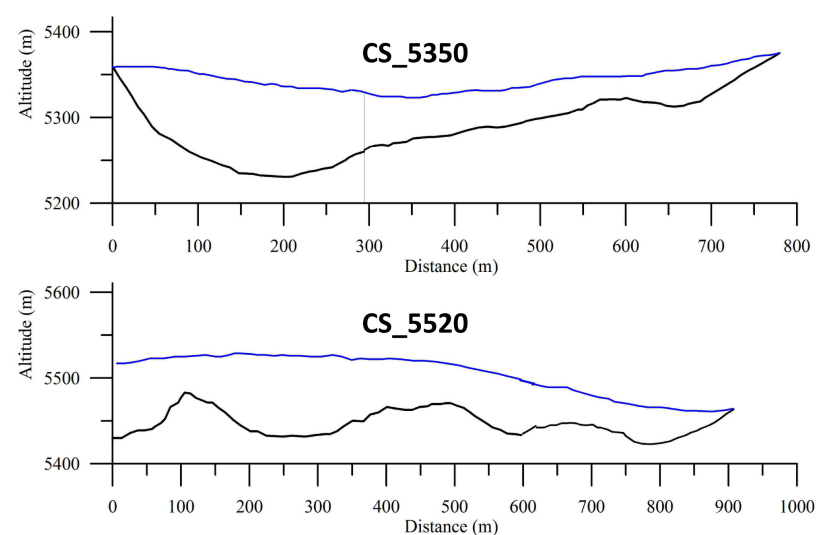

Fig. 10. Ice depths and surface topographies of the two main cross sections CS_5350 and CS_5520 at 5350 and $5520 \mathrm{~m}$ a.s.l. The vertical line at $\sim 300 \mathrm{~m}$ on CS_5350 represents a discontinuity in the surveyed profile (visible on Fig. 9).

assuming that all reflection points lie in the plane of the profile rather than an ellipsoid. The overall uncertainty on ice thickness is estimated at $\pm 15 \mathrm{~m}$. Given that the uncertainty on ice surface coordinates is low $( \pm 0.1 \mathrm{~m})$, the uncertainty on cross section areas mainly arises from the uncertainty on ice thickness and corresponds to $\pm 6400 \mathrm{~m}^{2}$ at $5350 \mathrm{~m}$ a.s.l. and $\pm 9200 \mathrm{~m}^{2}$ at $5520 \mathrm{~m}$ a.s.l.

\subsection{Ice fluxes}

The ice flux $Q\left(\mathrm{~m}^{3}\right.$ of ice per year) through the cross sections at $5350 \mathrm{~m}$ a.s.l. and $5520 \mathrm{~m}$ a.s.l. can be inferred using two distinct methods. First they were calculated using the kinematic method consisting in multiplying the cross sectional area $S_{\mathrm{c}}\left(\mathrm{m}^{2}\right)$ with the depth-averaged horizontal ice velocity $U\left(\mathrm{~m} \mathrm{yr}^{-1}\right)$.

$Q=U S_{\mathrm{c}}$

The depth-averaged horizontal ice velocity was derived from the mean surface ice velocity obtained by averaging the surface velocities available along each cross section (Sect. 5.4 and Fig. 9). Nye (1965) gives ratios of depth-averaged horizontal ice velocity to mean surface ice velocity varying from 0.8 (no sliding) to 1 (maximum sliding). The error range of the ice fluxes obtained with this method combines the error range for the cross-section areas and the above-mentioned ratio assumed to vary from 0.8 to 1 .

We also calculated ice fluxes using annual surface mass balances measured during 2007-2012. Although the dynamic changes are neglected here, this method allows us to estimate the ice fluxes for each section from mass-balance data according to the following equation:

$Q=\frac{1}{0.9} \sum_{z}^{z_{\max }} b_{i} s_{i}$ where $Q$ is the ice flux (converted into $\mathrm{m}^{3}$ of ice per year using an ice density of $900 \mathrm{~kg} \mathrm{~m}^{-3}$, hence the factor 1/0.9) at a given elevation, $z$, and $b_{i}$ is the annual mass balance of the altitudinal range $i$ of map area $s_{i}$. The altitudinal ranges taken into account in the calculation are the areas contributing ice to the cross section and thus located between $z$ and the altitude of the glacier top $z_{\max }$. In case of Mera Glacier, the upper areas only feeding the Mera branch and contributing ice to the two sections have been taken into account as shown in Fig. 9. We assume here that on each point of the glacier above this altitude, $z$, the surface elevation has remained unchanged from one year to the next. The uncertainties on ice fluxes resulting from surface mass balance are directly derived from the mass-balance uncertainties (see Sect. 4.1) assumed to be $\pm 0.28 \mathrm{~m}$ w.e. at every elevation of the areas contributing ice to each cross section and also from the uncertainties in delineating accurately these areas.

The ice fluxes calculated with both methods at each cross section are given in Table 3. Both methods have been described in details in Azam et al. (2012) and a comparison between methods allowed them to assess the state of balance of Chhota Shigri Glacier (western Himalaya) over the one or two decades prior to their measurements. In case of Mera Glacier, the mean values of ice fluxes at CS_5350 and CS_5520 inferred from $5 \mathrm{yr}$ of annual mass-balance data are higher than the respective values obtained with the kinematic method $\left(0.56 \times 10^{6}\right.$ vs. $0.18 \times 10^{6} \mathrm{~m}^{3}$ ice $\mathrm{yr}^{-1}$ at $5350 \mathrm{~m}$ a.s.1. and $0.73 \times 10^{6}$ vs. $0.38 \times 10^{6} \mathrm{~m}^{3}{\text { ice } \mathrm{yr}^{-1}}^{-1}$ at $5520 \mathrm{~m}$ a.s.1.). The flux difference between both sections $\left(\sim 0.2 \times 10^{6} \mathrm{~m}^{3}\right.$ ice $\left.\mathrm{yr}^{-1}\right)$ is approximately the same regardless of the method used here which gives confidence in the results. Moreover, the fact that fluxes obtained with the kinematic method are smaller than the mean flux derived from the 2007-2012 mass-balance data suggests that the mean mass-balance state of Mera Glacier over the last one or two decades corresponds to an averaged mass balance more negative than the observed 2007-2012 mean $\left(-0.08 \pm 0.28 \mathrm{~m}\right.$ w.e. $\left.\mathrm{yr}^{-1}\right)$. This kinematic flux is significantly higher than the flux inferred from the 2009-2010 mass balance data $\left(-0.48 \pm 0.28 \mathrm{mw}\right.$.e. $\mathrm{yr}^{-1}$; Table 3$)$ suggesting that the mean decadal mass-balance state of this glacier ranges between -0.48 and $-0.08 \mathrm{~m}$ w.e. $\mathrm{yr}^{-1}$.

\subsection{Comparison of annual and seasonal mass balances with meteorological conditions}

To evaluate the climatic influences on glacier mass balance, we compared annual or seasonal air temperature and precipitation records from Pyramid Observatory (5035 m a.s.l.; Fig. 1) with mass balance data (Table 2). First we had to reconstruct a complete series of monthly temperature and precipitation at Pyramid between November 2007 and October 2012 using data recorded in Khumbu valley. Data gaps in the Pyramid meteorological records were filled by applying a regression equation with the corresponding variable 
Table 3. Ice fluxes $Q\left(10^{6} \mathrm{~m}^{3}\right.$ ice $\left.\mathrm{yr}^{-1}\right)$, inferred from the kinematic method and from the annual mass balance data at each cross section surveyed in the field, i.e. at mean elevations of $5350 \mathrm{~m}$ a.s.l. and $5520 \mathrm{~m}$ a.s.l. respectively. For the sake of comparison the glacier-wide annual mass balances for the 5 surveyed years are also given (in parenthesis).

\begin{tabular}{|c|c|c|c|c|c|c|c|}
\hline Ice fluxes $Q$ & \multirow[t]{2}{*}{ kinematic } & \multicolumn{6}{|c|}{ inferred at each cross section from annual mass-balance data } \\
\hline $\begin{array}{l}\text { Years } \\
\text { (annual mass balance, } \mathrm{m} \text { w.e.) }\end{array}$ & & $\begin{array}{r}2007-08 \\
(0.39)\end{array}$ & $\begin{array}{r}2008-09 \\
(-0.10)\end{array}$ & $\begin{array}{r}2009-10 \\
(-0.48)\end{array}$ & $\begin{array}{r}2010-11 \\
(0.46)\end{array}$ & $\begin{array}{r}2011-12 \\
(-0.67)\end{array}$ & $\begin{array}{r}\text { Mean } \\
(-0.08)\end{array}$ \\
\hline Cross section at $5350 \mathrm{~m}$ a.s. 1 . & $0.18 \pm 0.06$ & $1.40 \pm 0.56$ & $0.62 \pm 0.56$ & $-0.02 \pm 0.56$ & $1.34 \pm 0.56$ & $-0.55 \pm 0.56$ & $0.56 \pm 0.56$ \\
\hline Cross section at $5520 \mathrm{~m}$ a.s.l. & $0.38 \pm 0.11$ & $1.53 \pm 0.53$ & $0.83 \pm 0.53$ & $0.27 \pm 0.53$ & $1.33 \pm 0.53$ & $-0.31 \pm 0.53$ & $0.73 \pm 0.53$ \\
\hline
\end{tabular}

recorded at Pheriche (4260 m a.s.1.) when available or otherwise at Namche Bazar (3570 m a.s.1.). At monthly time-step and over the whole 2003-2012 period, the Pyramid record is well-correlated with the Pheriche and Namche Bazar records for temperature $\left(r^{2}=0.95\right.$ and 0.83 respectively) and for precipitation ( $r^{2}=0.81$ and 0.86 respectively). We preferred not to reconstruct precipitation in 2008-2009 because there were too many gaps at all stations. In total only $13 \%$ and $8 \%$ of data have been reconstructed for temperature and precipitation respectively, suggesting that this reconstruction has a limited impact on the analysis.

We do not find any clear relationships between meteorological variables and mass balance data, at either seasonal or annual seasonal scales (Table 2). At most, it seems that negative mass balances are related to a deficit in precipitation during the monsoon, but this result needs to be confirmed with longer time-series.

\section{Discussion and conclusion}

\subsection{Seasonal mass balance}

Seasonal mass balance measurements on Mera and Pokalde glaciers confirm that ablation and accumulation are concomitant in summer which in turn is the key season controlling the annual glacier mass balance (Figs. 6-7). But, unexpectedly, these measurements also show that ablation can occur at any elevation in winter due to wind erosion and sublimation, with the majority of remobilized snow potentially sublimated in the atmosphere. This effect has been previously observed in other regions, as Pomeroy and Essery (1999) report that sublimation fluxes during blowing snow have been estimated to return $10-50 \%$ of seasonal snow to the atmosphere in North American prairie and arctic environments. Blowing snow sublimation is also a key process controlling the spatial variability of the snow cover of the dry Andes of Chile, amounting to $18 \%$ of the total ablation at high elevations (2600-5630 m a.s.1.) (Gascoin et al., 2013). In the Himalayas, this effect has not been quantified yet but meteorological conditions encountered at very high elevations in winter (low temperatures and humidity, high wind speeds) are similar to those of arctic environments, or even windier, leading to significant in-transit sublimation.

Known as "summer-accumulation type glaciers" (e.g. Ageta and Higuchi, 1984), Nepalese glaciers might also be referred as "winter-ablation type glaciers" even though further observations are needed to confirm it. This striking feature may have significant impact on mountain hydrology. Indeed, one of the largest unknowns for assessments of water resources and for the understanding of high altitude hydrology remains the accurate quantification of the spatial distribution of precipitation in mountain regions (e.g. Immerzeel et al., 2012). Addressing this issue in Nepal and more generally in the monsoon-influenced Himalaya will not be achieved without implementing snow transport models (e.g. Vionnet et al., 2013) to better understand the redistribution and the sublimation of the snow by the wind at glacier elevations.

\subsection{Mass-balance gradients}

The mass balance gradients reported on Mera Glacier (from 0.45 to $0.85 \mathrm{~m}$ w.e. $(100 \mathrm{~m})^{-1}$ depending on the orientation) are roughly similar to the gradients observed in the Alps or on other mid-latitude glaciers (e.g. Rabatel et al., 2005; Zemp et al., 2009; Shea et al., 2013) or in western Himalaya on Chhota Shigri Glacier (Wagnon et al., 2007). Considered together with the value measured on Pokalde Glacier $\left(1.51 \mathrm{~m}\right.$ w.e. $\left.(100 \mathrm{~m})^{-1}\right)$, these gradients from both glaciers of our study are comparable to values reported previously on Yala Glacier $\left(0.81 \mathrm{~m}-1.3 \mathrm{~m}\right.$ w.e. $(100 \mathrm{~m})^{-1}$, 1996) (Fujita et al., 1998); AX010 Glacier (0.81-0.9 m w.e. $(100 \mathrm{~m})^{-1}$, 1996-1999) (Fujita et al., 2001a) and Rikha Samba Glacier $\left(0.64 \mathrm{~m}\right.$ w.e. $\left.(100 \mathrm{~m})^{-1}, 1999\right)$ (Fujita et al., 2001b). Consequently, the mass-balance gradients of Nepalese glaciers can vary at least threefold, from $0.5 \mathrm{mw}$.e. $(100 \mathrm{~m})^{-1}$ to $1.5 \mathrm{~m}$ w.e. $(100 \mathrm{~m})^{-1}$ depending on the location (which drives the local climate and especially the amount of precipitation received by the glacier), the size and the aspect of the glacier.

In the Himalayan region, snow and glacier melt models based on ablation gradient usually use a single value for mass balance gradient (e.g. Racoviteanu et al., 2013) and 
they could be significantly improved by applying various gradients according to aspect, size, and climatic setting of the glaciers. Mass balance gradients over debris-covered glaciers also need to be investigated, and process-based studies on Changri Nup Glacier, located a few km northwest of Pokalde Glacier, were initiated in 2010 (Lejeune et al., 2013).

\subsection{Recent mass-balance conditions}

Over the period 2007-2012, the glacier-wide mass balance of Mera Glacier was slightly negative at $-0.08 \pm 0.28 \mathrm{~m}$ w.e. $\mathrm{yr}^{-1}$. Pokalde Glacier lost mass more rapidly than Mera Glacier with a mean glacier-wide mass balance of $-0.72 \pm 0.28 \mathrm{mw}$ w.e. $\mathrm{yr}^{-1}$ compared to $-0.23 \pm 0.28 \mathrm{~m}$ w.e. $\mathrm{yr}^{-1}$ for Mera Glacier over the common 2009-2012 period (Table 2). The very negative mass balance observed on Pokalde Glacier is probably due to the lower elevation and the smaller area of its accumulation area. Such glaciers located at lower altitudes are often smaller and easier to access and therefore usually preferred for in-situ observations. Consequently, compilations of ground-based mass balances are very likely biased toward negative values compared with the regional mean under the present-day climate (Fujita and Nuimura, 2011; Gardner et al., 2013). Our comparison between Mera and Pokalde glaciers seems to confirm this fact. Low-elevation glaciers like Pokalde Glacier are sometimes reduced to a single ablation zone, with the ELA above their upper reaches like in 2011-2012 (Table 2). These glaciers are no longer in equilibrium with the present climate and would disappear in the near future if climatic conditions similar to 2011-2012 prevail.

Even though the periods do not properly match, these values for Mera Glacier are not statistically different from the values recently reported by Gardelle et al. (2013) between 1999 and 2010 over $1461 \mathrm{~km}^{2}$ of glacierized area in Everest region $\left(-0.26 \pm 0.13 \mathrm{~m}\right.$ w.e. $\left.\mathrm{yr}^{-1}\right)$. Moreover, the ice fluxes obtained by the kinematic method allow us to infer the state of balance of Mera Glacier over the last one or two decades (Azam et al., 2012). The kinematic fluxes through CS_5520 and CS_5350 are lower than the fluxes obtained with a mass balance of $-0.08 \pm 0.28 \mathrm{~m}$ w.e. $\mathrm{yr}^{-1}$ (= mean annual mass balance from 2007 to 2012) and higher than the fluxes obtained with a mass balance of $-0.48 \pm 0.28 \mathrm{~m}$ w.e. $\mathrm{yr}^{-1}$ (=2009-2010 mass balance) (Table 3). Consequently, mean decadal mass-balance conditions of Mera Glacier are comprised between both above-mentioned values in agreement again with Gardelle et al. (2013). If conditions observed between 2007 and 2012 prevail in the future, the glacier might accelerate in the coming years as suggested by the fact that cross section ice fluxes inferred from the mean 2007-2012 mass balance data are significantly higher than kinematic ice fluxes. In the map showing the glacier-elevation changes of this region (Gardelle et al., 2013; their Fig. 4), it is notable that Mera Glacier, probably due to its more southerly and wetter position, shrinks less rapidly than glaciers located fur- ther north in the mountain range. This feature is confirmed by our observations of more negative mass balances for Pokalde Glacier than for Mera Glacier.

Between 2009 and 2012, both glaciers show a similar cumulative centred mass balance ( $=$ annual value - mean value over the three years for every glacier) revealing that interannual mass balance fluctuations are very similar between both glaciers, regardless of their size and their position inside the mountain range (Fig. 6 and Table 2). This striking consistency, which has been previously observed in other mountain ranges over longer time periods (e.g. Vincent et al., 2005; Huss et al., 2010), indicates that the mass balances of both study glaciers respond to a common regional climatic signal.

\subsection{Unclear link between meteorological and mass balance variability}

As seen in Sect. 5.7, no clear relationship between temperature or precipitation and annual or seasonal mass balance data could be found, except a weak link between glacier mass loss and a deficit in monsoon precipitation (Table 2). Mölg et al. (2013) demonstrated quantitatively that monsoon onset (i.e. June mainly) strongly affects the ablation season of glaciers in Tibet, with late monsoon onset causing negative mass balances because of lower accumulation and enhanced ablation due to an increased absorption of short-wave incoming radiation. But so far no clear relationship between the monsoon onset and annual mass balances could be retrieved from our too-short dataset.

We attempted to reconstruct meteorological data at hourly time-step in order to discriminate snow and rain at Pyramid and to extrapolate this to glacier elevations using a temperature lapse rate derived from monsoon data at Pyramid and Pheriche $\left(-5.75^{\circ} \mathrm{C} \mathrm{km}^{-1}\right)$ and a rain-snow temperature threshold assumed to be $1^{\circ} \mathrm{C}$. This analysis showed that in some years (2010-2011 and 2011-2012), up to $28 \%$ of the total monsoon precipitation may fall as rain at $5500 \mathrm{~m}$ a.s.l. with probably significant impacts on the surface energy balance of glaciers and consequently on mass balance in the ablation area. But again, our reconstructed climatic dataset at hourly time-step was not accurate or long enough to clearly understand the drivers of the large mass-balance inter-annual variability between 2007 and 2012. Since the annual glacierwide mass balance is mainly controlled by summer ablation and accumulation conditions, this inter-annual variability depends mainly on the Indian monsoon variability. It is likely that moderately negative mass balances of central Himalayan glaciers over the last decade are due to the weakening of the Indian monsoon (Bollasina et al., 2011) or a delay of the monsoon onset (Mölg et al., 2012) or a combination of both. Both phenomena may lead to higher atmospheric temperatures (and thus snowfall replaced by rainfall at glacier elevations), lower precipitation (Yao et al., 2012) and an increase in the available energy for ablation primarily through changes in absorbed short-wave radiation. 
A thorough climatic analysis including data from the surface energy balance station located at $5360 \mathrm{~m}$ a.s.l. on Mera Glacier and run since 2011 (Fig. 1) and an in-depth comparison with meteorological records available from nearby stations is still required and will be conducted in the future.

In conclusion, our observations on Mera Glacier, combined with findings from recent remote-sensing studies in the Everest area (Bolch et al., 2011; Nuimura et al., 2012; Gardelle et al., 2013), confirm that glaciers in this region may slightly lose mass. Though our observation period is relatively short, the rate of observed specific mass loss is significantly lower than the global glacier mass wastage $\left(-0.42 \pm 0.05 \mathrm{~m}\right.$ w.e. $\mathrm{yr}^{-1}$ over $2003-2009$ when glaciers at the periphery of Greenland and Antarctica are excluded) reported by Gardner et al. (2013), and is three to four times lower than that observed for glaciers in the European Alps, whose mean mass balance over the last decade is around $-1 \mathrm{~m}$ w.e. $\mathrm{yr}^{-1}$ (Huss, 2012), Long-term monitoring of Mera and Pokalde glaciers is required to study a poorly-known and seemingly complex relationship between glaciers and climate in eastern Nepal. This programme, planned for the coming years, will include winter and summer mass balance measurements, surveys of thickness changes and energy balance studies on Mera Glacier and on other debris-covered glaciers in the region.

Acknowledgements. This work has been supported by the French Service d'Observation GLACIOCLIM and the French National Research Agency through ANR-09-CEP-005-01/PAPRIKA. This study was carried out within the framework of the Ev-K2-CNR Project in collaboration with the Nepal Academy of Science and Technology as foreseen by the Memorandum of Understanding between Nepal and Italy, and thanks to contributions from the Italian National Research Council, the Italian Ministry of Education, University and Research and the Italian Ministry of Foreign Affairs. All people involved in the field or helping for logistical support at the Pyramid, in Kathmandu or in Italy are greatly acknowledged here. We thank J. P. Chazarin, R. Biron and the porters who have been involved in successive field trips, sometimes in harsh conditions. S. Kaspari measured the stakes on 23-25 April 2009, and is greatly acknowledged here. Pleiades-1A images were obtained free of charge in the framework of the "Recette Thématique Utilisateur Pléiades/ORFEO" conducted by the French Space Agency (CNES). The SPOT5 DEM and images were obtained thanks to ISIS proposals \#397 and \#520. E. Berthier acknowledges support from the CNES through the TOSCA programme. J. Shea and D. Stumm acknowledge institutional support from ICIMOD, and financial support from the Royal Norwegian Embassy in Kathmandu. E. Thibert helped to calculate the mass balance accuracy and is greatly acknowledged here. The authors are sincerely grateful to M. Pelto, T. Mölg, P. Lardeux, B. Raup, S. Ommanney and the two referees T. Nuimura and C. Mayer for their valuable comments which greatly helped to improve this paper.

Edited by: J. O. Hagen

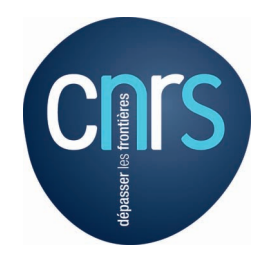

The publication of this article is financed by CNRS-INSU.

\section{References}

Ageta, Y. and Higuchi, K.: Estimation of mass balance components of a summer-accumulation type glacier in the Nepal Himalaya, Geogr. Ann. A, 66, 249-255, 1984.

Ageta, Y. and Fujita, K.: Characteristics of mass balance of summeraccumulation type glaciers in the Himalayas and Tibetan Plateau, Z. Gletscherkd. Glazialgeol., 32, 61-65, 1996.

Ageta, Y., Ohata, T., Tanaka, Y., Ikegami, K., and Higuchi, K.: Mass balance of Glacier AX010 in Shorong Himal, east Nepal during the summer monsoon season, Seppyo, J. Jpn. Soc. Snow Ice, 41, 34-41, 1980.

Arendt, A., Bolch, T., Cogley, J. G., Gardner, A., Hagen, J.-O., Hock, R., Kaser, G., Pfeffer, W. T., Moholdt, G., Paul, F., Radic', V., Andreassen, L., Bajracharya, S., Beedle, M., Berthier, E., Bhambri, R., Bliss, A., Brown, I., Burgess, E., Burgess, D., Cawkwell, F., Chinn, T., Copland, L., Davies, B., de Angelis, H., Dolgova, E., Filbert, K., Forester, R., Fountain, A., Frey, H., Giffen, B., Glasser, N., Gurney, S., Hagg, W., Hall, D., Haritashya, U. K., Hartmann, G., Helm, C., Herreid, S., Howat, I., Kapustin, G., Khromova, T., Kienholz, C., Koenig, M., Kohler, J., Kriegel, D., Kutuzov, S., Lavrentiev, I., LeBris, R., Lund, J., Manley, W., Mayer, C., Miles, E., Li, X., Menounos, B., Mercer, A., Moelg, N., Mool, P., Nosenko, G., Negrete, A., Nuth, C., Pettersson, R., Racoviteanu, A., Ranzi, R., Rastner, P., Rau, F., Rich, J., Rott, H., Schneider, C., Seliverstov, Y., Sharp, M., Sigurðsson, O., Stokes, C., Wheate, R., Winsvold, S., Wolken, G., Wyatt, F., and Zheltyhina, N.: Randolph Glacier Inventory [v2.0]: A Dataset of Global Glacier Outlines, Global Land Ice Measurements from Space, Boulder Colorado, USA, Digital Media, http: //www.glims.org/RGI/randolph.html (last access: 19 November 2013), 2012.

Azam, M. F., Wagnon, P., Ramanathan, A., Vincent, C., Sharma, P., Arnaud, Y., Linda, A., Pottakkal, J., Chevallier, P., Singh, V. B., and Berthier, E.: From balance to imbalance: a shift in the dynamic behaviour of Chhota Shigri Glacier (Western Himalaya, India), J. Glaciol., 58, 315-324, doi:10.3189/2012JoG11J123, 2012.

Bajracharya, S. R. and Mool, P. K.: Glaciers, glacial lakes and glacial lake outburst floods in the Mount Everest region, Nepal, Ann. Glaciol., 50, 81-86, 2009.

Bolch, T., Pieczonka, T., and Benn, D. I.: Multi-decadal mass loss of glaciers in the Everest area (Nepal Himalaya) derived from stereo imagery, The Cryosphere, 5, 349-358, doi:10.5194/tc-5349-2011, 2011.

Bolch, T., Kulkarni, A., Kääb, A., Huggel, C., Paul, F., Cogley, J. G., Frey, H., Kargel, J. S., Fujita, K., Scheel, M., Bajracharya, S., and Stoffel, M.: The State and Fate of Himalayan Glaciers, Science, 336, 310-314, 2012.

Bollasina, M., Ming, Y., and Ramaswamy, V.: Anthropogenic aerosols and the weakening of the South Asian summer mon- 
soon, Science, 334, 502-505, doi:10.1126/science.1204994, 2011.

Bookhagen, B. and Burbank, D. W.: Topography, relief, and TRMM-derived rainfall variations along the Himalaya, Geophys. Res. Lett., 33, L08405, doi:10.1029/2006GL026037, 2006.

Bookhagen, B. and Burbank, D. W.: Toward a complete Himalayan hydrological budget: Spatiotemporal distribution of snowmelt and rainfall and their impact on river discharge, J. Geophys. Res., 115, F03019, doi:10.1029/2009JF001426, 2010.

Burbank, D. W., Blythe, A. E., Putkonen, J., Bratt-Sitaula, B., Gabet, E., Oskin, M., Barros, A., and Ojha, T. P.: Decoupling of erosion and precipitation in the Himalayas, Nature, 426, 652-655, doi:10.1038/nature02187, 2003.

Cogley, J. G., Kargel, J. S., Kaser, G., and Van der veen, C.J.: Tracking the Source of Glacier Misinformation, Science, 327, p. 522, 2010 .

Cuffey, K. M. and Paterson, W. S. B.: The physics of glaciers, Fourth ed., Academic Press Inc, Amsterdam, 2010.

Fujita, K. and Nuimura, T.: Spatially heterogeneous wastage of Himalayan glaciers, Proc. Natl. Acad. Sci., 108, 14011-14014, 2011.

Fujita, K., Takeuchi, Y., and Seko, K.: Glaciological observations of Yala Glacier in Langtang Valley, Nepal Himalaya, 1994 and 1996, Bull. Glacier Res., 16, 75-81, 1998.

Fujita, K., Kadota, T., Rana, B., Kayastha, R. B., and Ageta, Y.: Shrinkage of Glacier AX010 in Shorong region, Nepal Himalayas in the 1990s, Bull. Glacier Res., 18, 51-54, 2001a.

Fujita K., Nakazawa, F., and Rana B.: Glaciological observations on Rikha Samba Glacier in Hidden Valley, Nepal Himalayas, 1998 and 1999, Bull. Glacier Res., 18, 31-35, $2001 \mathrm{~b}$.

Gardelle, J., Berthier, E., Arnaud, Y., and Kääb, A.: Region-wide glacier mass balances over the Pamir-Karakoram-Himalaya during 1999-2011, The Cryosphere, 7, 1263-1286, doi:10.5194/tc7-1263-2013, 2013.

Gardner, A. S., Moholdt, G., Cogley, J. G., Wouters, B., Arendt, A. A., Wahr, J., Berthier, E., Pfeffer, T., Kaser, G., Hock, R., Ligtenberg, S. R. M., Bolch, T., Sharp, M., Hagen, J. O., van den Broeke, M. R., and Paul, F.: A consensus estimate of glacier contribution to sea level rise: 2003 to 2009, Science, 340, 852857, doi:10.1126/science.1234532, 2013.

Gascoin, S., Lhermitte, S., Kinnard, C., Bortels, K., and Liston, G. E.: Wind effects on snow cover in Pascua-Lama, Dry Andes of Chile, Adv. Water Resour., 55, 25-39, 2013.

Haeberli, W., Maisch, M., and Paul, F.: Mountain glaciers in global climate-related observational network, WMO Bulletin, 51, 1825, 2002.

Harrison, W. D., Elsberg, D. H. Cox, L. H., and March, R. S.: Different mass balances for climatic and hydrologic applications, J. Glaciol., 51, p. 176, 2005.

Hubbard, B. and Glasser, N.: Field Techniques in Glaciology and Glacial Geomorphology, Wiley and Sons Ltd, Chichester, England, 400 pp., 2005.

Huss, M.: Extrapolating glacier mass balance to the mountain-range scale: the European Alps 1900-2100, The Cryosphere, 6, 713727, doi:10.5194/tc-6-713-2012, 2012.

Huss, M., Hock, R., Bauder, A., and Funk, M.: 100year mass changes in the Swiss Alps linked to the Atlantic Multidecadal Oscillation, Geophys. Res. Lett., 37, doi:10.1029/2010GL042616, 2010.
Immerzeel, W. W., van Beek, L. P. H., and Bierkens, M. F. P.: Climate Change Will Affect the Asian Water Towers, Science, 328, 1382-1385, 2010.

Immerzeel, W. W., Pellicciotti, F., and Shrestha, A. B.: Glaciers as a proxy to quantify the spatial distribution of precipitation in the Hunza Basin, Mt. Res. Dev., 32, 30-38, doi:10.1659/MRDJOURNAL-D-11-00097.1, 2012.

Kääb, A., Berthier, E., Nuth, C., Gardelle, J., and Arnaud, Y.: Contrasting patterns of early 21 st century glacier mass change in the Himalaya, Nature, 488, 495-498, doi:10.1038/nature11324, 2012.

Kadota, T., Seko, K., Aoki, T., Iwata, S., and Yamaguchi, S.: Shrinkage of Khumbu Glacier, east Nepal from 1978 to 1995, IAHS Publ., 264, 235-243, 2000.

Kaser, G., Großhauser, M., and Marzeion, B.: Contribution potential of glaciers to water availability in different climate regimes, Proc. Natl. Acad. Sci., 107, 20223-20227, doi:10.1073/pnas.1008162107, 2010.

Kehrwald, N. M., Thompson, L. G., Tandong, Y., MosleyThompson, E., Schotterer, U., Alfimov, V., Beer, J., Eikenberg, J., and Davis, M. E.: Mass loss on Himalayan glacier endangers water resources, Geophys. Res. Lett., 35, L22503, doi:10.1029/2008GL035556, 2008.

Korona, J., Berthier, E., Bernard, M., Remy, F., and Thouvenot, E.: SPIRIT. SPOT 5 stereoscopic survey of Polar Ice: Reference Images and Topographies during the fourth International Polar Year (2007-2009), ISPRS J. Photogramm., 64, 204-212, doi:10.1016/j.isprsjprs.2008.10.005, 2009.

Lejeune, Y., Bertrand, J. M., Wagnon, P., and Morin, S.: A physically based model for the year-round energy and mass balance of debris-covered glaciers, J. Glaciol., 50, 327-344, 2013.

Leprince S., Barbot, S., Ayoub, F., and Avouac, J. P.: Automatic and Precise Orthorectification, Coregistration, and Subpixel Correlation of Satellite Images, Application to Ground Deformation Measurements, IEEE Transactions Geosci. and Remote Sens., 45, 1529-1557, 2007.

Mölg, T., Maussion, F., Yang, W., and Scherer, D.: The footprint of Asian monsoon dynamics in the mass and energy balance of a Tibetan glacier, The Cryosphere, 6, 1445-1461, doi:10.5194/tc6-1445-2012, 2012.

Narod, B. B. and Clarke, G. K. C.: Miniature high-power impulse transmitter for radio-echo sounding, J. Glaciol., 40, 190-194, 1994.

Neil, S., Nathalie, V., Bart, N., and Dennis, P. L.: The contribution of glacier melt to streamflow, Environ. Res. Lett., 7, 034029, 2013.

Nepal, S., Krause, P., Flügel, W.-A., Fink, M., and Fisher, C.: Understanding the hydrological system dynamics of a glaciated alpine catchment in the Himalayan region using J2000 hydrological model, Hydrol. Process., doi:10.1002/hyp.9627, 2012.

Nuimura, T., Fujita, K., Fukui, K., Asahi, K., Aryal, R., and Ageta, Y.: Temporal changes in elevation of the debris-covered ablation area of Khumbu Glacier in the Nepal Himalaya since 1978, Arct. Antarct. Alp. Res., 43, 246-255, 2011.

Nuimura, T., Fujita, K., Yamaguchi, S., and Sharma, R. R.: Elevation changes of glaciers revealed by multitemporal digital elevation models calibrated by GPS survey in the Khumbu region, Nepal Himalaya, 1992-2008, J. Glaciol., 58, 648-656, doi:10.3189/2012JoG11J061, 2012. 
Nye, J. F.: The flow of a glacier in a channel of rectangular, elliptic or parabolic cross section, J. Glaciol., 5, 661-690, 1965.

Olyphant, G. A.: Longwave radiation in mountainous areas and its influence on the energy balance of alpine snowfields, Water Resour. Res., 22, 62-66, 1986.

Paul, F., Kääb, A., and Haeberli, W.: Recent glacier changes in the Alps observed by satellite: Consequences for future monitoring strategies, Global Planet. Change, 56, 111-122, 2007.

Pomeroy, J. W. and Essery, R. L. H.: Turbulent fluxes during blowing snow: field tests and model sublimation predictions, Hydrol. Process., 13, 2963-2975, 1999.

Rabatel, A., Dedieu, J. P., and Vincent, C.: Using remote-sensing data to determine equilibrium-line altitude and mass-balance time series: validation on three French glaciers, 1994-2002, J. Glaciol., 51, 539-546, 2005.

Racoviteanu, A. E., Armstrong, R., and Williams, M. W.: Evaluation of an ice ablation model to estimate the contribution of melting glacier ice to annual discharge in the Nepalese Himalaya, Water Resour. Res., 49, 1-17, doi:10.1002/wrcr.20370, 2013.

Scherler, D., Bookhagen, B., and Strecker, M. R.: Spatially variable response of Himalayan glaciers to climate change affected by debris cover, Nat. Geosci., 4, 156-159, 2011.

Shea, J. M., Menounos, B., Moore, R. D., and Tennant, C.: An approach to derive regional snow lines and glacier mass change from MODIS imagery, western North America, The Cryosphere, 7, 667-680, doi:10.5194/tc-7-667-2013, 2013.

Shrestha, D., Singh, P., and Nakamura, K.: Spatiotemporal variation of rainfall over the central Himalayan region revealed by TRMM Precipitation Radar, J. Geophys. Res., 117, D22106, doi:10.1029/2012JD018140, 2012.

Thibert, E., Blanc, R., Vincent C., and Eckert, N.: Glaciological and volumetric mass-balance measurements: error analysis over 51 years for Glacier de Sarennes, French Alps, J. Glaciol., 54, 522532, 2008.

Vincent, C., Lemeur, E., Six, D., and Funk, M.: Solving the paradox of the end of the Little Ice Age in the Alps, Geophys. Res. Lett., 32, L09706, doi:10.1029/2005GL022552, 2005.

Vincent, C., Ramanathan, Al., Wagnon, P., Dobhal, D. P., Linda, A., Berthier, E., Sharma, P., Arnaud, Y., Azam, M. F., Jose, P. G., and Gardelle, J.: Balanced conditions or slight mass gain of glaciers in the Lahaul and Spiti region (northern India, Himalaya) during the nineties preceded recent mass loss, The Cryosphere, 7, 569582, doi:10.5194/tc-7-569-2013, 2013.
Vionnet, V., Martin, E., Masson, V., Guyomarc'h, G., NaaimBouvet, F., Prokop, A., Durand, Y., and Lac, C.: Simulation of wind-induced snow transport in alpine terrain using a fully coupled snowpack/atmosphere model, The Cryosphere Discuss., 7, 2191-2245, doi:10.5194/tcd-7-2191-2013, 2013.

Wagnon, P., Linda, A., Arnaud, Y., Kumar, R., Sharma, P., Vincent, C., Pottakkal, J. G., Berthier, E., Ramanathan, A., Hasnain, S. I., and Chevallier, P.: Four years of mass balance on Chhota Shigri Glacier, Himachal Pradesh, India, a new benchmark glacier in the western Himalaya, J. Glaciol., 53, 603-611, 2007.

Wagnon, P., Lafaysse, M., Lejeune, Y., Maisincho, L., Rojas, M., and Chazarin, J. P.: Understanding and modeling the physical processes that govern the melting of snow cover in a tropical mountain environment in Ecuador, J. Geophys. Res., 114, D19113, doi:10.1029/2009JD012292, 2009.

Wang, B.: The Asian monsoon, 787 pp., Springer, Berlin, 2006.

Webster, P. J., Magana, V. O., Palmer, T. N., Shukla, J., Tomas, R. A., Yanai, M., and Yasunari,. T.: Monsoons: Processes, predictability, and the prospects for prediction, J. Geophys. Res., 103, 14451-14510, doi:10.1029/97JC02719, 1998.

Yao, T., Thompson, L. G., Yang, W. Yu, W., Gao, Y., Guo, X., Yang, X., Duan, K., Zhao, H., Xu, B., Pu, Y., Lu, A., Xiang, Y., Kattel, D. B., and Joswiak, D.: Different glacier status with atmospheric circulations in Tibetan Plateau and surroundings, Nature Clim. Change, 2, 663-667, doi:10.1038/NCLIMATE1580, 2012.

Zhang T., Xiao, C., Colgan, W., Qin, X., Du, W., Sun, W., Liu, Y., and Ding, M.: Observed and modelled ice temperature and velocity along the main flowline of East Rongbuk Glacier, Qomolangma (Mount Everest), Himalaya, J. Glaciol., 59, 438-448, doi:10.3189/2013JoG12J202, 2013.

Zemp, M., Hoezle, M., and Haeberli, W.: Six decades of glacier mass-balance observations: a review of worldwide monitoring network, Ann. Glaciol., 50, 101-111, 2009.

Zemp, M., Thibert, E., Huss, M., Stumm, D., Rolstad Denby, C., Nuth, C., Nussbaumer, S. U., Moholdt, G., Mercer, A., Mayer, C., Joerg, P. C., Jansson, P., Hynek, B., Fischer, A., Escher-Vetter, H., Elvehøy, H., and Andreassen, L. M.: Reanalysing glacier mass balance measurement series, The Cryosphere, 7, 12271245, doi:10.5194/tc-7-1227-2013, 2013. 